\title{
1,3-Dipolar Cycloadditions of N-Benzyl Furfuryl Nitrones with Electron-rich Alkenes
}

\author{
Pedro Merino*, Sonia Anoro, Francisco L. Merchan and Tomas Tejero \\ Departamento de Quimica Organica. Facultad de Ciencias-ICMA. Universidad de Zaragoza. E-50009 \\ Zaragoza. Aragon. Spain
}

Fax: +34 976 762075, E-mail: pmerino@posta.unizar.es

*Author to whom correspondence should be addressed.

Presented in part at the Third Electronic Conference on Synthetic Organic Chemistry (ECSOC-3). September, 1-30, 1999. URL: http://www.unibas.ch/mdpi/ecsoc-3.htm

Received: 25 January 2000 / Accepted: 14 February 2000 / Published: 18 February 2000

\begin{abstract}
The 1,3-dipolar cycloaddition reaction of N-benzyl-C-(2-furyl)nitrones with electron-rich alkenes gives preferentially trans-substituted 3,5-disubstituted isoxazolidines (endo approach). These experimental results are in good qualitative agreement with the predicted ones by semiempirical (AM1 and PM3) and ab initio (HF/3-21G) methods.
\end{abstract}

Keywords: Nitrones, isoxazolidines, pyrrolidines, theoretical calculations, cycloaddition.

\section{Introduction}

While abundant information on the reactivity of several classes of nitrones exists [1], hetaryl nitrones, i.e. nitrones bearing an heterocyclic ring at the carbon atom, have been the subject of very few investigations [2]. Recent publications from this laboratory have been concerned with the use of C-(2-thiazolyl) and C-(2-furyl)nitrones $\mathbf{1}$ and $\mathbf{2}$ as suitable substrates for both nucleophilic additions [3] and 1,3-dipolar cycloadditions [4]. We also provided a theoretical study of the 1,3-dipolar cycloadditions of several hetaryl nitrones with methyl acrylate [5]. Our continued interest in the reactivity of hetaryl nitrones, which has been scarcely explored, led us to investigate the reaction of C(2-furyl)nitrones $\mathbf{2}$ with electron-rich alkenes and in this paper we report on these results.

(C) 2000 by MDPI (http://www.mdpi.org). Reproduction is permitted for noncommercial purposes. 
<smiles>[Li][N+]([O-])=Cc1nccs1</smiles>

1a $R^{1}=B n$

1b $R^{1}=P M B$<smiles>[Li][N+]([O-])=Cc1ccco1</smiles>

2a $R^{1}=B n$

2b $\quad R^{1}=P M B$

\section{Scheme 1.}

\section{Results}

Furan-derived nitrones were prepared according to our method [6] from furfural and the corresponding benzyl hydroxylamine. In both cases only the Z-isomer was detected, the configuration being assigned on the basis of NOE experiments (a 10-12\% enhancement was observed in the difference spectra upon irradiation of the azomethine proton of the nitrone and the benzylic protons. Further confirmation arose from the recording of the corresponding ${ }^{1} \mathrm{H}$ NMR spectra in deuterochloroform and hexadeuterobenzene. The observed ASIS effect [7] confirmed the Zconfiguration of nitrones $\mathbf{2}$. In addition it was possible to obtain a single crystal of $\mathbf{2 a}$ whose X-ray diffraction analysis confirmed a Z-configuration [8].
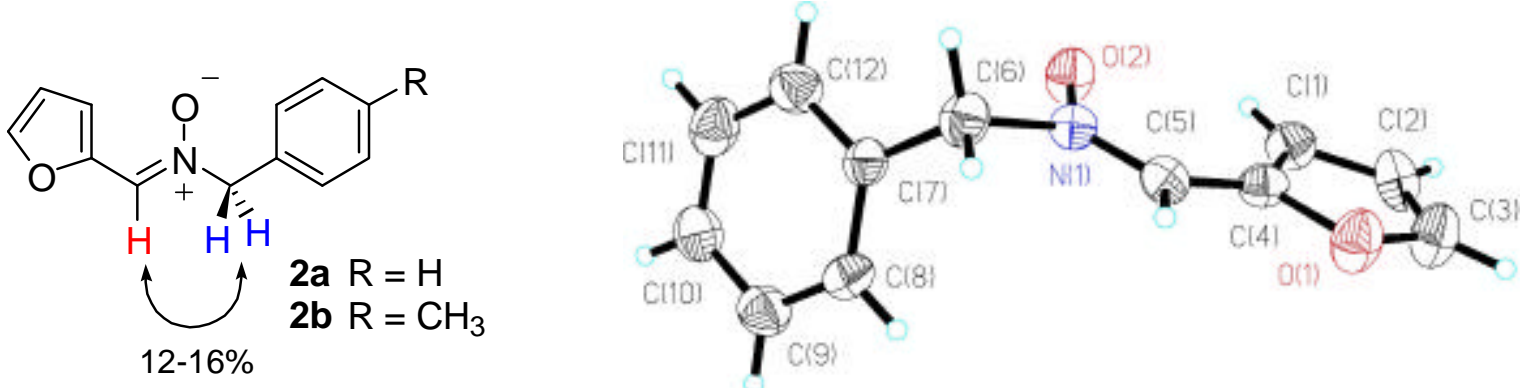

Figure 1. Z-configuration of N-benzyl-C-(2-furyl)nitrones (left: observed NOE's; right: ORTEP representation of $\mathbf{2 a}$ showing ellipsoids at $50 \%$ probability level).

The configurational stability of nitrones $\mathbf{2}$ was also checked. After refluxing in toluene for a week no changes in their structure were observed and the E-isomer could not be detected in any instance.

Refluxing nitrones $\mathbf{2}$ either in a solvent or neat with an excess of alkene $\mathbf{3}$ until TLC indicated disappearance of the nitrone afforded a mixture of isoxazolidines (Scheme 2).<smiles>[R]N=Cc1ccco1</smiles>

2a $R^{1}=B n \quad 3 a R^{2}=A c$

2b $R^{1}=P M B \quad 3 b R^{2}=E t$<smiles>[R]OC1CC(c2ccco2)NO1</smiles>

4<smiles>[R7]O[C@@H]1C[C@H](c2ccco2)NO1</smiles>

5

\begin{tabular}{|c|c|c|}
\hline & $\mathrm{R}^{1}$ & $\mathrm{R}^{2}$ \\
\hline & $\mathrm{Bn}$ & $A c$ \\
\hline & PMB & $A c$ \\
\hline & $\mathrm{Bn}$ & Et \\
\hline & PMB & Et \\
\hline
\end{tabular}

Scheme 2. 
Table 1. Cycloaddition of nitrones 2 with alkenes 3 .

\begin{tabular}{|c|c|c|c|cc|c|}
\hline entry & $\mathrm{R}^{1}$ & $\mathrm{R}^{2}$ & reaction conditions & $\mathbf{4}$ & $\mathbf{5}$ & yield(\%) \\
\hline 8 & $\mathrm{Bn}$ & $\mathrm{OEt}$ & Toluene / reflux / 10 d & 40 & 60 & 25 \\
\hline 8 & $\mathrm{Bn}$ & $\mathrm{OEt}$ & neat / reflux / 10 d & 45 & 55 & 56 \\
\hline 9 & $\mathrm{Bn}$ & $\mathrm{OAc}$ & $\mathrm{CHCl}_{3} /$ reflux / 10 d & 12 & 88 & 36 \\
\hline 9 & $\mathrm{Bn}$ & $\mathrm{OAc}$ & $\mathrm{Toluene}^{2}$ reflux / 10 d & 26 & 74 & 48 \\
\hline 9 & $\mathrm{Bn}$ & $\mathrm{OAc}$ & neat / reflux / 10 d & 40 & 60 & 58 \\
\hline 9 & $\mathrm{PMB}$ & $\mathrm{OEt}$ & Toluene / reflux / 13 d & 38 & 62 & 53 \\
\hline 16 & $\mathrm{PMB}$ & $\mathrm{OEt}$ & neat / reflux / 10 d & 41 & 59 & 48 \\
\hline 17 & $\mathrm{PMB}$ & $\mathrm{OAc}$ & $\mathrm{CHCl}_{3} /$ reflux / 17 d & 40 & 60 & 16 \\
\hline 18 & $\mathrm{PMB}$ & $\mathrm{OAc}$ & neat / reflux / 10 d & 35 & 65 & 43 \\
\hline
\end{tabular}

Bn: benzyl; PMB: p-methoxybenzyl

The obtained crude mixture was analyzed by NMR to determine the ratio of isomers, and the corresponding adducts were separated by preparative centrifugally accelerated radial thin layer chromatography (see experimental). The isoxazolidines obtained are indicated in Scheme 2 and the corresponding reaction conditions, selectivities and yields in Table 1.

For the purpose of comparison, the cycloaddition of nitrones 2 with disubstituted electron-poor alkenes, e.g. dimethyl fumarate and dimethyl maleate was also studied [9]. The results of this study are illustrated in Scheme 3 and summarized in Table 2.

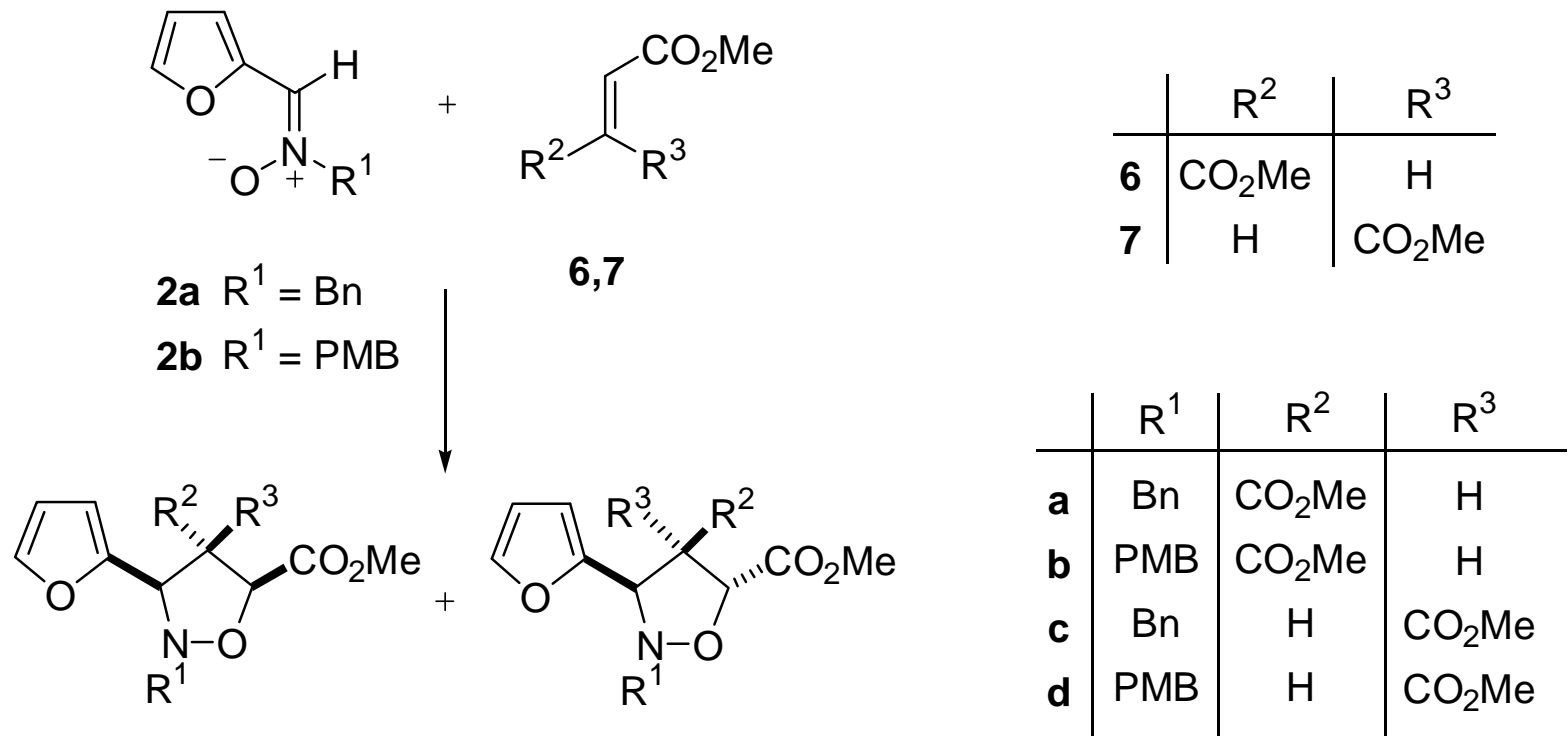

8a-d

9a-d

Scheme 3. 
Table 2. Cycloaddition of nitrones 2 with alkenes 6-7.

\begin{tabular}{|c|c|c|c|c|cc|c|}
\hline entry & $\mathrm{R}^{1}$ & $\mathrm{R}^{2}$ & $\mathrm{R}^{3}$ & reaction conditions & $\mathbf{8}$ & $\mathbf{9}$ & yield(\%) \\
\hline 1 & $\mathrm{Bn}$ & $\mathrm{CO}_{2} \mathrm{Me}$ & $\mathrm{H}$ & $\mathrm{CH}_{2} \mathrm{Cl}_{2} /$ reflux / 48 h & 47 & 53 & 91 \\
\hline 2 & $\mathrm{Bn}$ & $\mathrm{CO}_{2} \mathrm{Me}$ & $\mathrm{H}$ & Toluene / reflux / 12 h & 61 & 39 & 54 \\
\hline 3 & $\mathrm{Bn}$ & $\mathrm{H}$ & $\mathrm{CO}_{2} \mathrm{Me}$ & 1,2 -DCE / reflux / 16 h & 81 & 19 & 79 \\
\hline 4 & $\mathrm{Bn}$ & $\mathrm{H}$ & $\mathrm{CO}_{2} \mathrm{Me}$ & Toluene / reflux / 12 h & 82 & 18 & 89 \\
\hline 5 & $\mathrm{PMB}$ & $\mathrm{CO}_{2} \mathrm{Me}$ & $\mathrm{H}$ & Toluene / reflux / 12 h & 93 & 7 & 86 \\
\hline 6 & $\mathrm{PMB}$ & $\mathrm{H}$ & $\mathrm{CO}_{2} \mathrm{Me}$ & Toluene / reflux / 12 h & 85 & 15 & 83 \\
\hline
\end{tabular}

Bn: benzyl; PMB: p-methoxybenzyl

The structure and stereochemistry of isoxazolidines $\mathbf{4}, \mathbf{5}, \mathbf{8}$ and 9 were ascertained by careful examination of the ${ }^{1} \mathrm{H}$ NMR spectra (using, when necessary, homonuclear proton NMR decoupling) and nuclear Overhausser effect (NOE) experiments. Compounds $\mathbf{4}$ and $\mathbf{5}$ showed the same ${ }^{1} \mathrm{H}$ NMR trend (doublet-of-doublets) for H-3 and H-5 protons, thus allowing the assignment of the regiochemistry. In addition, the ${ }^{1} \mathrm{H}$ NMR spectra of these compounds exhibited two well-defined doublet-of-doublet-of-doublets thereby confirming the substitution pattern of the oxazolidie ring. (see experimental for proton assignments).

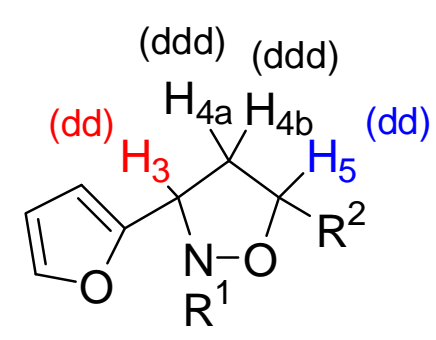

4,5

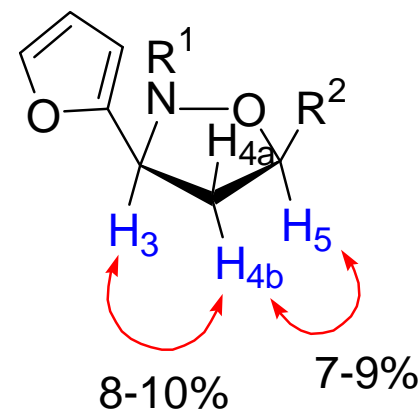

4

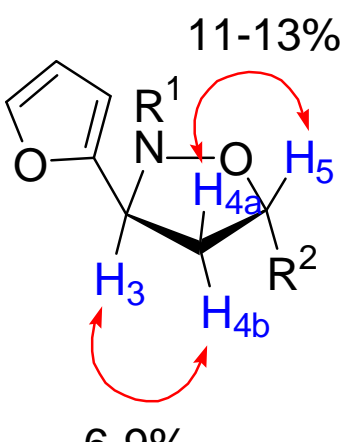

$6-9 \%$

5

Figure 2. ${ }^{1} \mathrm{H}$ NMR multiplicities of isoxazolidines and selected NOE data for isoxazolidines.

The analysis of vicinal coupling constants $\mathbf{J}_{3,4}$ and $\mathbf{J}_{4,5}$ did not result in an unambiguous configurational assignment of isoxazolidines $4, \mathbf{5}, \mathbf{8}$ and $\mathbf{9}$. We have used nuclear Overhausser effects obtained by difference spectroscopy experiments for establishing the relative stereochemistry of the ring substituents (Figure 2). The irradiation of $\mathrm{H}-4 \mathrm{~b}$ in $\mathbf{4}$ resulted in enhancement of the signals for $\mathrm{H}-3$ and $\mathrm{H}-5$. On the other hand, no effect was detected upon irradiation of H-4a. The same experiment performed on products 5 produced signal enhancements for H-3 when H-4b was irradiated and for H-5 
upon irradiation of $\mathrm{H}-4 \mathrm{a}$. All these effects are in agreement with a cis configuration for compounds 4 and a trans configuration for 5.The configuration of compounds $\mathbf{8}$ and $\mathbf{9}$ was also established by NOE experiments. In addition compounds 8 and 9 were transformed into the corresponding pyrrolidin-2ones (Scheme 4) 10 and 11. NOE experiments were also carried out with these compounds in order to further assess the relative configuration of the substituents.<smiles>[R]C1([R])C(C(C)=O)ONC1c1ccco1</smiles>

$8 a-d$<smiles>[R7][C@@]1([2H])[C@@H](C(=O)OC)ON[C@H]1c1ccco1</smiles>

9a-d

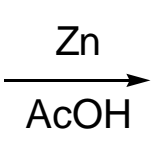

AcOH

$\underset{\mathrm{AcOH}}{\stackrel{\mathrm{An}}{\longrightarrow}}$

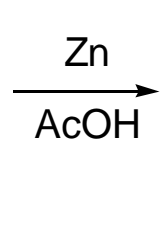

\begin{tabular}{c|c|c|c} 
& $\mathrm{R}^{1}$ & $\mathrm{R}^{2}$ & $\mathrm{R}^{3}$ \\
\hline $\mathbf{a}$ & $\mathrm{Bn}$ & $\mathrm{CO}_{2} \mathrm{Me}$ & $\mathrm{H}$ \\
$\mathbf{b}$ & $\mathrm{PMB}$ & $\mathrm{CO}_{2} \mathrm{Me}$ & $\mathrm{H}$ \\
$\mathbf{c}$ & $\mathrm{Bn}$ & $\mathrm{H}$ & $\mathrm{CO}_{2} \mathrm{Me}$ \\
d & $\mathrm{PMB}$ & $\mathrm{H}$ & $\mathrm{CO}_{2} \mathrm{Me}$
\end{tabular}<smiles>[R7]C1NC(=O)[C@@H](O)C1([R])[R]</smiles>

10a-d<smiles></smiles>

11a-d

\section{Scheme 4.}

\section{Discussion}

The stereochemical outcome of the cycloadditions did not appear to be affected by the electron density of the dipolarophile. Both with electron-rich (Table 1) and electron-deficient (Table 2) alkenes similar results were obtained. In the case of vinyl acetate and ethyl vinyl ether the 3,5-regioisomers were obtained as the only adducts. This observed regioselectivity is in agreement with previously reported data for other nitrones [10]. A frontier molecular orbitals treatment showed that the HOMO(nitrone)-LUMO(alkene) interactions dominate the reactions in the case of electron-deficient alkenes and vinyl acetate.

In the case of cycloaddition with ethyl vinyl ether the interactions LUMO(nitrone)-HOMO(alkene) are more favorable [11]. In this case the smallest HOMO-LUMO gap exists for the LUMO of the nitrone and the HOMO of the alkene. The energies and the coefficients of the HOMO and LUMO of nitrones 2 and alkenes 3 calculated at a semiempirical level (MOPAC97, PM3) [12] were shown in Figure 3 (methyl acrylate is shown for comparison). The PM3-calculated FMO energies and the corresponding energy gaps for HOMO-LUMO interactions are given in Table 3 (favorable interactions are shown in blue; unfavorable interactions are shown in red). 

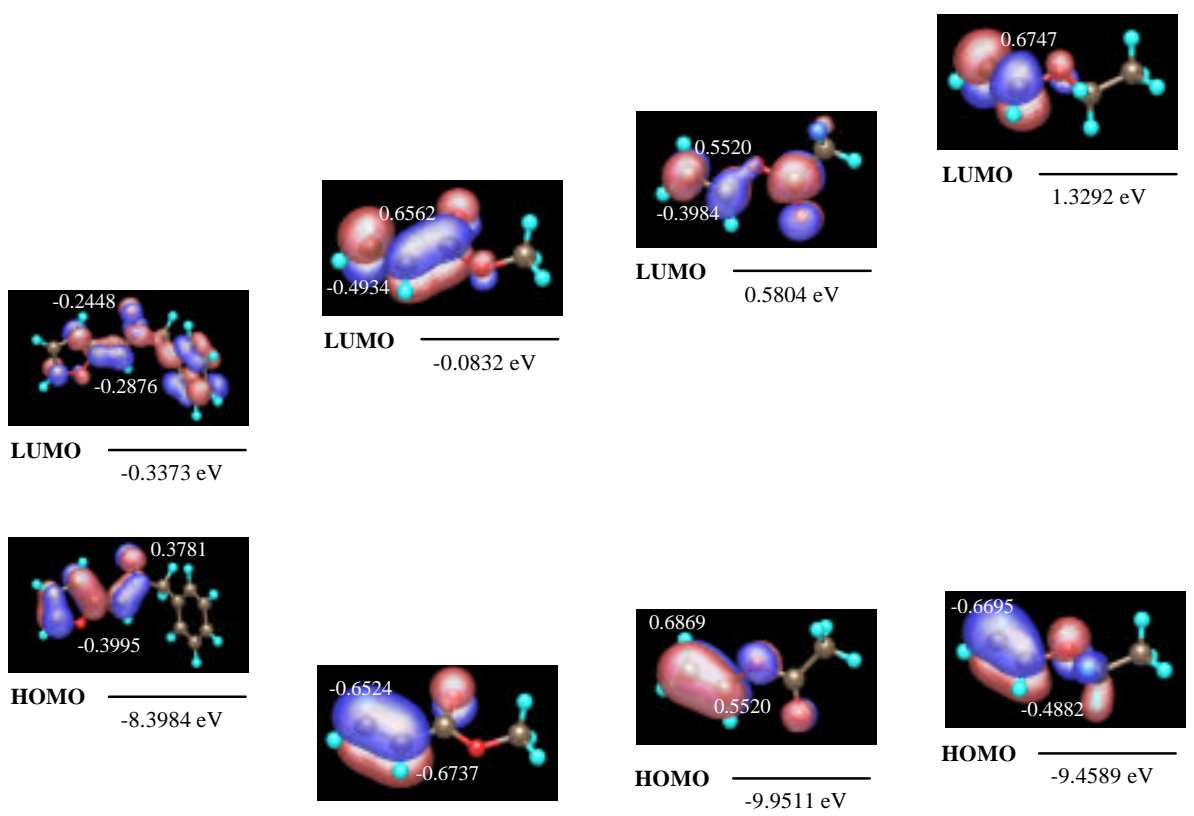

номо

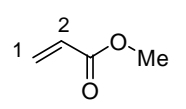

$3 c$

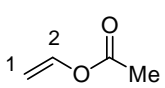

$3 a$ 3b

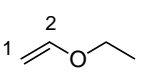

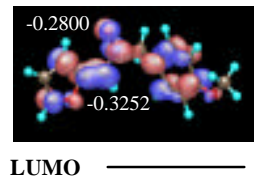

$-0.2869 \mathrm{eV}$

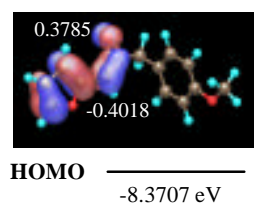

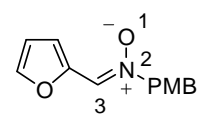

2b

Figure 3. PM3-calculated FMO energies and atomic contributions for $\mathbf{2}$ and $\mathbf{3}$.

Table 3. PM3-calculated FMO energies and energy gaps for the cycloaddition of 2 with vinyl acetate $\mathbf{3 a}$, ethyl vinyl ether $\mathbf{3 b}$ and methyl acrylate $\mathbf{3 c}$.

\begin{tabular}{|c|c|c|c|c|c|c|c|c|c|}
\cline { 2 - 10 } \multicolumn{2}{c|}{} & \multicolumn{4}{c|}{ HOMO-nitrone } & \multicolumn{5}{c|}{ LUMO-nitrone } \\
\hline $\begin{array}{c}\text { LUMO- } \\
\text { alkene }\end{array}$ & $\mathbf{2 a}$ & -8.3984 & $\mathbf{2 b}$ & -8.3707 & $\begin{array}{c}\text { HOMO- } \\
\text { alkene }\end{array}$ & $\mathbf{2 a}$ & -0.3373 & $\mathbf{2 b}$ & -0.2869 \\
\hline $\mathbf{3 a}$ & 0.5804 & 8.9788 & 8.9511 & $\mathbf{3 a}$ & -9.9511 & 9.6138 & 9.6642 \\
\hline $\mathbf{3 b}$ & 1.3292 & 9.7276 & 9.7000 & $\mathbf{3 b}$ & -9.4589 & 9.1216 & 9.1720 \\
\hline $\mathbf{3 c}$ & -0.0832 & 8.3152 & \multicolumn{2}{|c|}{8.2875} & $\mathbf{3 c}$ & -11.0669 & 10.7296 & 10.7800 \\
\hline
\end{tabular}

These energy gaps are in good qualitative agreement with the observed reactivity. The lowest difference in FMO's energies was observed for cycloadditions to methyl acrylate. On the other hand values higher than $0.6 \mathrm{eV}$ were found for cycloadditions to electron-rich alkenes $\mathbf{3 a}$ and $\mathbf{3 b}$. Therefore, it is not surprising that a lower reactivity was observed for cycloadditions with vinyl acetate and ethyl vinyl ether with respect to those with methyl acrylate [4b]. The observed regioselectivity can be explained by the magnitude of the atomic components in the FMO of interest. Thus, for cycloadditions with methyl acrylate [4b] and vinyl acetate the atom with the calculated larger HOMO coefficient on the nitrone reacts with the atom with the larger LUMO coefficient of the alkene. 
To discuss the stereoselectivities observed in the 1,3-dipolar cycloadditions studies it is required a careful evaluation of the different effects which can operate in the transition states leading to two diastereomeric cis and trans cycloadducts. The possibility of interconversion of the $\mathrm{E}$ and $\mathrm{Z}$ forms of the nitrones, although suggested for several authors [13], can be discarded on the basis of the proven stability of compounds $\mathbf{2}$ (vide supra). The preferential formation of trans isoxazolidines $\mathbf{5}$ can be explained by assuming an endo-approach of the dipolarophile to the nitrone. In order to corroborate this hypothesis, we carried out a theoretical study of the cycloaddition reaction by using both semiempirical[14] and ab initio methods[15]. We studied the cycloaddition of nitrones 2 with both vinyl acetate and ethyl vinyl ether [16]. For the purpose of comparison all optimized structures including the reactants, transition states and products were calculated at AM1, PM3 and HF/3-21G levels. The theoretical study included the starting system (nitrone and alkenes), the transition states and the primary cycloadduct for both endo and exo approaches. The more stable conformation was chosen for nitrone and alkenes. A PES exploration of the nitrone was made in order to find the absolute minimum corresponding to the more stable conformation. For vinyl acetate and methyl vinyl ether scis conformations were used (Figure 4). Sum of the calculated energies of nitrone and alkene was considered to be the energy of the reactants. The optimized geometries of the nitrone and alkenes showed the expected bond lengths and angles. In fact, rather similar structural data were obtained when the optimized geometry of the nitrone was compared with its X-ray structure [8].

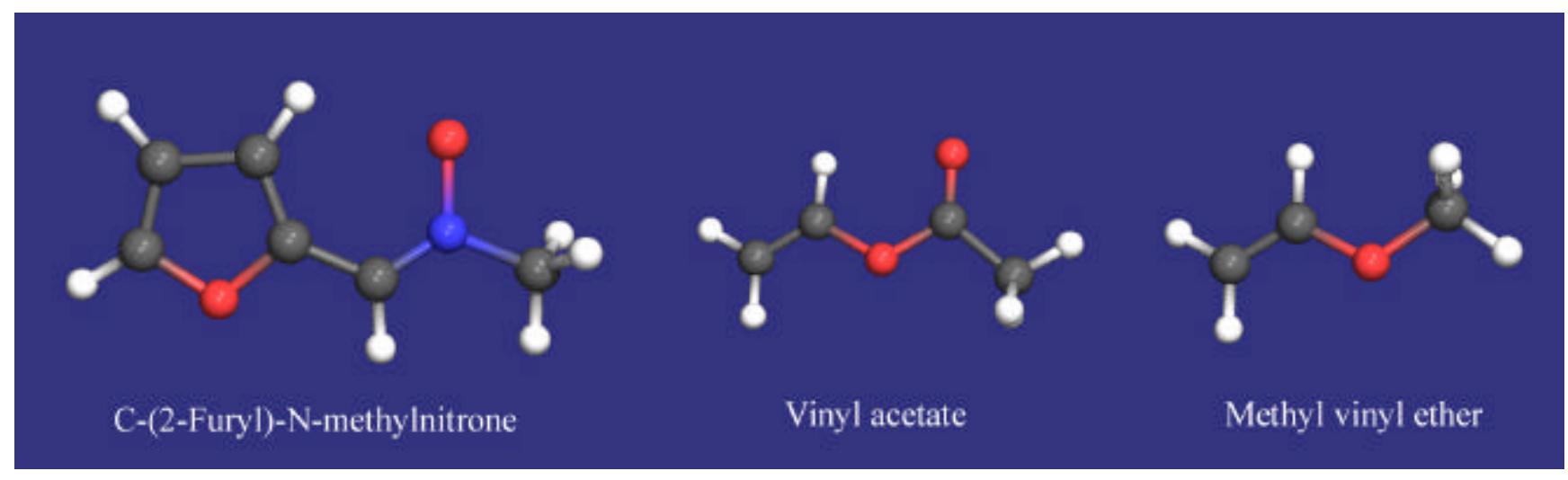

Figure 4. Optimized (HF/3-21G) structures for nitrone $\mathbf{2}$ and alkenes $\mathbf{3 a}$ and $\mathbf{3 b .}$

The TSs for the endo and exo approaches of vinyl acetate (TSa(endo) and TSa(exo)) and methyl vinyl ether ( $\mathrm{TSb}$ (endo) and $\mathrm{TSb}$ (exo)) to the nitrone were located by the calculation of a reaction path profile starting from optimized geometries of the corresponding isoxazolidines, followed by an optimization of the TS with respect to all structural variables. The TSs were characterized through the calculation of the force constant matrix by ensuring that they had one and only one imaginary harmonic vibrational frequency corresponding to the formation of new bonds. 


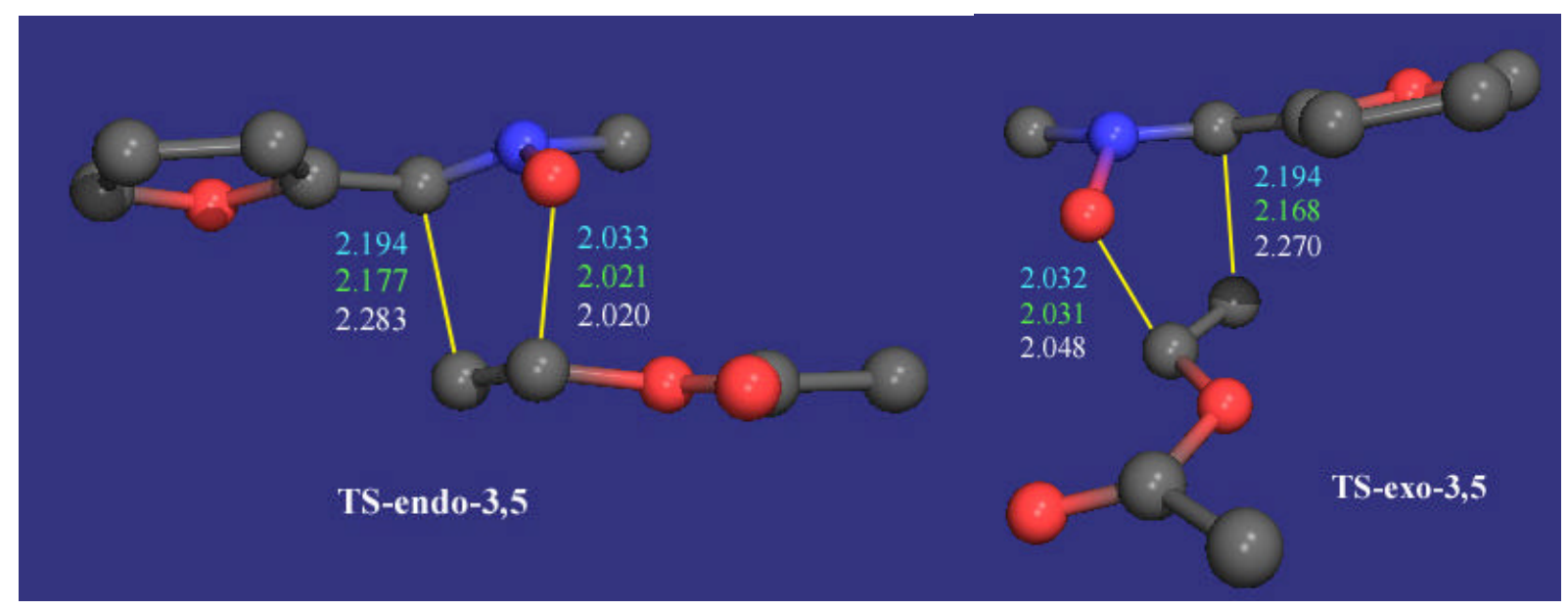

Figure 5. Transition states for the reaction of 2 with 3a. Bonds distances are given in amstrongs (AM1 in cyan, PM3 in green and HF/3-21G in white). The hydrogen atoms have been omitted for clarity.

By intrinsic reaction coordinate calculation the transition states, the reagents and the corresponding cycloadducts were confirmed to be in the same reaction coordinate. In all cases the ZPE corrections were evaluated by carrying out the corresponding frequency analysis. The optimized transition structures are illustrated in Figures 5 and 6 and the calculated parameters are given in Table 4.

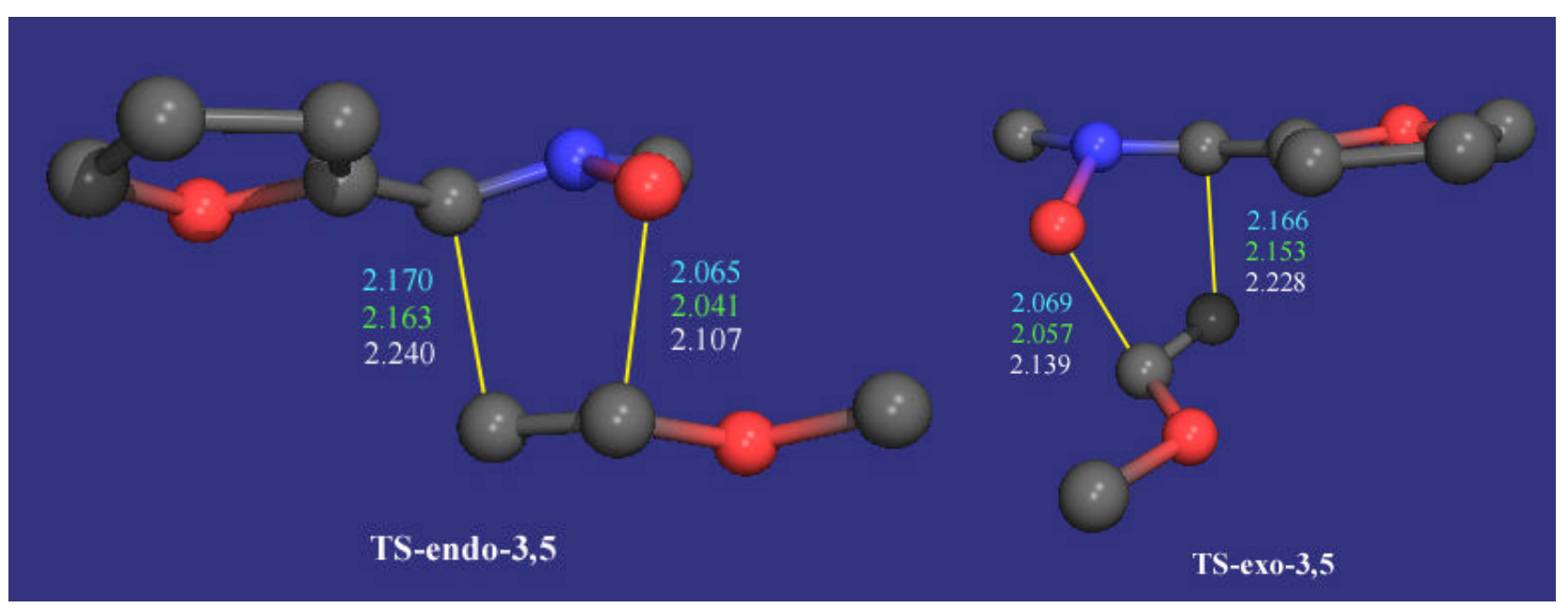

Figure 6. Transition states for the reaction of $\mathbf{2}$ with $\mathbf{3 b}$. Bonds distances are given in amstrongs (AM1 in cyan, PM3 in green and HF/3-21G in white). The hydrogen atoms have been omitted for clarity. 
Table 4. Semiempirical and $a b$ initio energies of ground states, transition structures and adducts for cycloadditions of $\mathbf{2}$ with alkenes $\mathbf{3}$.

\begin{tabular}{|c|c|c|c|}
\hline structure & $\begin{array}{c}\text { AM1 } \\
\left(\mathrm{kcal} \mathrm{mol}^{-1}\right) \\
\end{array}$ & $\begin{array}{c}\text { PM3 } \\
\left(\mathrm{kcal} \mathrm{mol}^{-1}\right)\end{array}$ & $\begin{array}{c}\mathrm{HF} / 3-21 \mathrm{G}^{*} \\
\text { (Hartrees) }^{\mathrm{c}}\end{array}$ \\
\hline nitrone $\mathbf{2} \mathrm{a}^{\mathrm{b}}$ & 27.46 & 9.05 & -432.764765 \\
\hline vinyl acetate & -67.86 & -68.54 & -302.880245 \\
\hline methylvinyl ether & -25.69 & -23.73 & -190.785715 \\
\hline TSa(endo) & $\begin{array}{l}-19.69 \\
(20.71) \\
\end{array}$ & $\begin{array}{l}-26.34 \\
(33.16) \\
\end{array}$ & $\begin{array}{c}-735.612270 \\
(20.54) \\
\end{array}$ \\
\hline $\mathrm{TSa}(\mathrm{exo})$ & $\begin{array}{l}-18.58 \\
(21.82) \\
\end{array}$ & $\begin{array}{l}-25.93 \\
(33.56) \\
\end{array}$ & $\begin{array}{c}-735.610633 \\
(21.57) \\
\end{array}$ \\
\hline TSb(endo) & $\begin{array}{c}20.68 \\
(18.91) \\
\end{array}$ & $\begin{array}{c}17.59 \\
(32.27) \\
\end{array}$ & $\begin{array}{c}-623.496836 \\
(33.66)\end{array}$ \\
\hline $\mathrm{TSb}(\mathrm{exo})$ & $\begin{array}{c}22.30 \\
(20.54)\end{array}$ & $\begin{array}{r}18.90 \\
(33.58)\end{array}$ & $\begin{array}{c}-623.493286 \\
(35.89)\end{array}$ \\
\hline trans $-\mathbf{5} \mathbf{a}, \mathbf{b}^{\mathrm{b}, \mathrm{d}}$ & -80.67 & -97.69 & -735.719216 \\
\hline$c i s-\mathbf{4 a}, \mathbf{b}^{\mathrm{b}, \mathrm{e}}$ & -79.14 & -96.48 & -735.717813 \\
\hline $\operatorname{trans}-\mathbf{5} \mathbf{c}, \mathbf{d}^{\mathrm{b}, \mathrm{f}}$ & -39.03 & -51.09 & -623.602537 \\
\hline$c i s-\mathbf{4} \mathbf{c}, \mathbf{d}^{\mathrm{b}, \mathrm{g}}$ & -37.27 & -50.44 & -623.600680 \\
\hline
\end{tabular}

${ }^{\mathrm{a}}$ For TSs potential energy barriers are given in brackets and red colour. ZPVE correction has been evaluated. ${ }^{\mathrm{b}}$ For simplicity the N-benzyl group of the nitrone was replaced by a methyl group. ${ }^{c}$ Energy barriers given in $\mathrm{kcal} \mathrm{mol}^{-1}{ }^{\mathrm{d}}$ from $\mathrm{TSa}(\mathrm{endo}){ }^{\mathrm{e}}$ from $\mathrm{TSa}(\mathrm{exo}) .{ }^{\mathrm{f}}$ from TSb(endo). ${ }^{\mathrm{g}}$ from TSb(exo).

As expected for 1,3-dipolar cycloadditions all TSs were asynchronous, the newly created C-O bond being formed to a greater extent than the $\mathrm{C}-\mathrm{C}$ bond. The differences between the semiempirical and $a b$ initio values of the $\mathrm{C}-\mathrm{O}$ and $\mathrm{C}-\mathrm{C}$ forming bonds are about 0.05 . The energies of the TSs depend on the approximation. In Figures 7 and 8 the energy profiles are shown for the cycloaddition of nitrone to both vinyl acetate and methyl vinyl ether (with inclusion of ZPVE), respectively. 


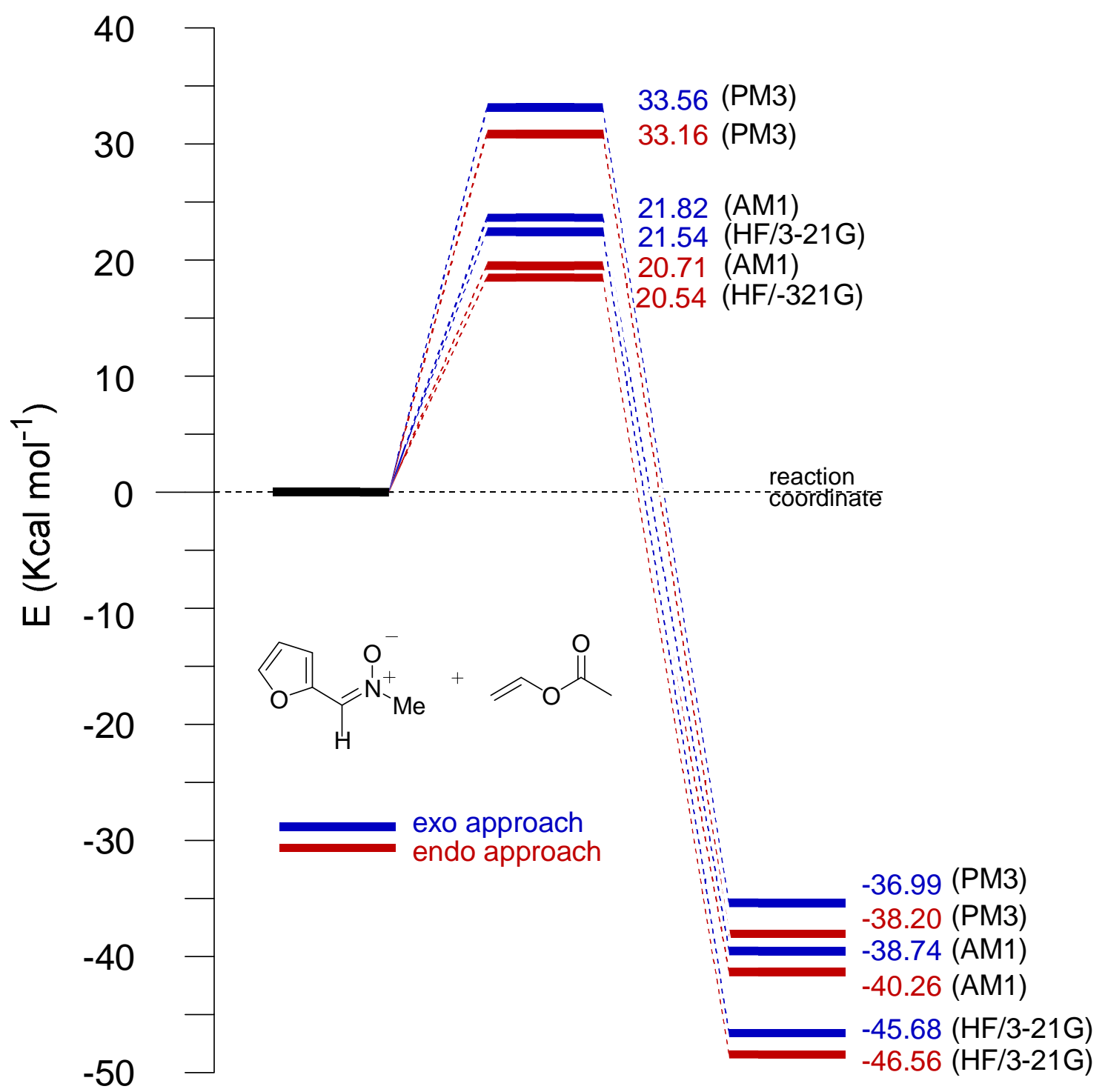

Figure 7. Reaction profiles for the reaction of $\mathbf{2}$ with $\mathbf{3 a}$ (endo and exo approaches are shown in red and blue, respectively) according to the AM1, PM3, and HF/3-21G procedures.

In all cases, irrespective of the level of calculation, experimental results are qualitatively well reproduced by the calculations, which showed the endo approach (leading to trans adducts) to be the most favorable. Nevertheless, the calculated energy barriers for endo and exo approaches indicate that the reaction should led to the formation of cis/trans mixtures of cycloadducts.

Interestingly, in the case of cycloaddition with vinyl acetate the energy barriers obtained with PM3 are larger than those corresponding to AM1 and HF/3-21G, which, in turn, are rather similar. On the other hand, for the cycloaddition with vinyl methyl ether, rather different values of energy barriers we obtained for AM1 calculations. These latter values were shown to be lower than those obtained from PM3 and HF/3-21G calculations. In this case, however, these two approaches gave rise to similar values. 


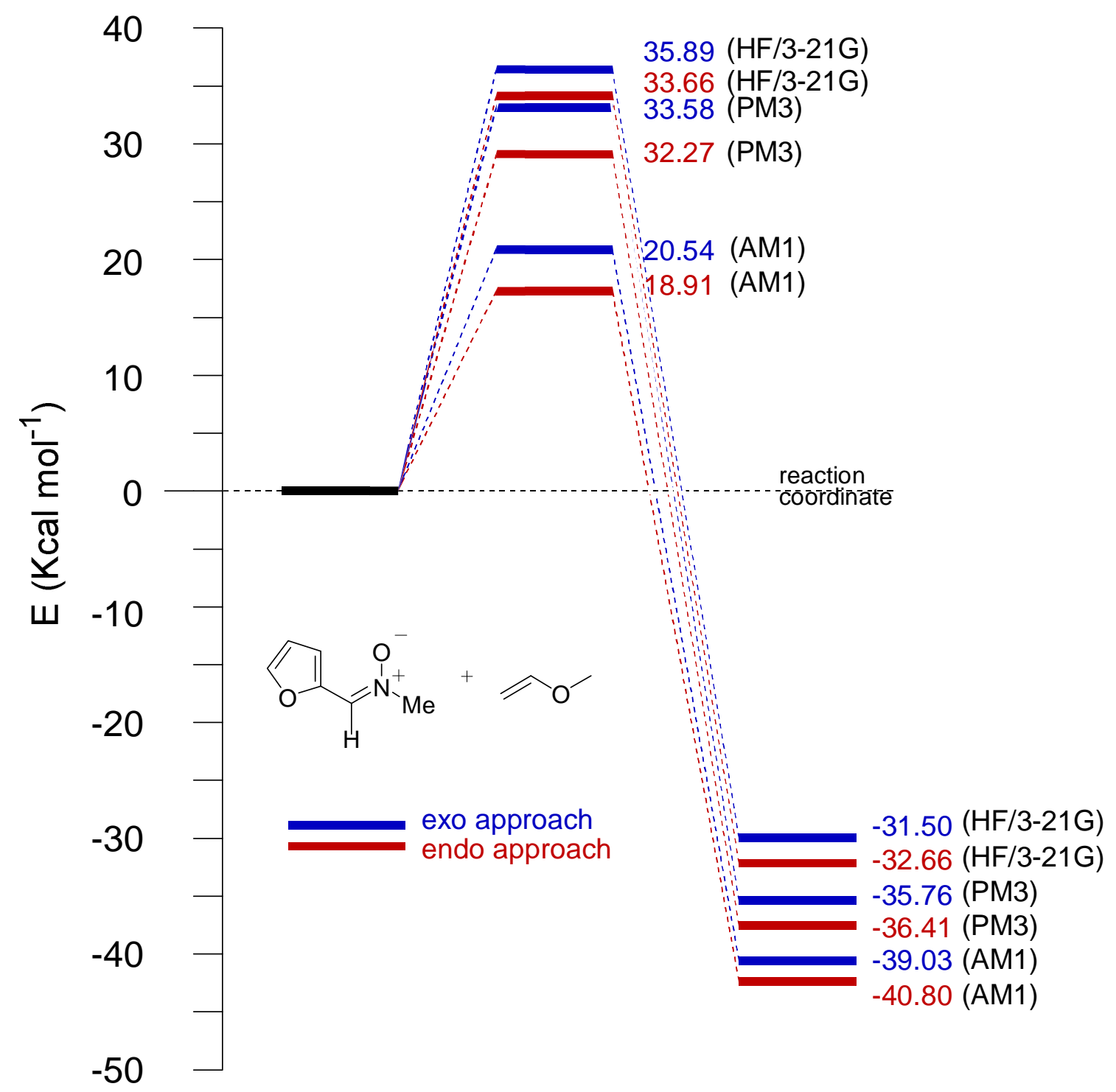

Figure 8. Reaction profiles for the reaction of $\mathbf{2}$ with $\mathbf{3 b}$ (endo and exo approaches are shown in red and blue, respectively) according to the AM1, PM3, and HF/3-21G procedures.

\section{Conclusion}

In conclusion, our studies have revealed that the 1,3-dipolar cycloaddition of N-benzyl-C-(2-furyl) nitrones with electron-rich alkenes gives predominantly trans-3,5-disubstituted isoxazolidines although in lower yields than with electron-deficient alkenes. The regiochemistry of the cycloaddition seems to be controlled by FMO interactions, whereas the stereochemistry of the cycloaddition is mainly dominated by the preference for an endo approach. Such a preference is qualitatively well-reproduced by both semiempirical and ab initio calculations. With these results in hand, we are now expanding this reaction to other hetaryl nitrones and applying it to the synthesis of several nitrogenated compounds. 


\section{Experimental}

\section{General}

The reaction flasks and other glass equipment were heated in an oven at $130^{\circ} \mathrm{C}$ overnight and assembled in a stream of Ar. All solvents were dried by the usual methods. All reactions were monitored by TLC on silica gel 60 F254; the position of the spots were detected with $254 \mathrm{~nm}$ UV light or by spraying with one of the following staining systems: $50 \%$ methanolic sulfuric acid, $5 \%$ ethanolic phosphomolybdic acid and iodine. Preparative column chromatography was performed on columns of silica gel (60-240 mesh) and with solvents that were distilled prior to use. Preparative centrifugally accelerated radial thin-layer chromatography (PCAR-TLC) was performed with a Chromatotron ${ }^{\circledR}$ Model 7924 T (Harrison Research, Palo Alto, CA, USA); the rotors (1 or $2 \mathrm{~mm}$ layer thickness) were coated with silica gel Merck grade type 7749, TLC grade, with binder and fluorescence indicator (Aldrich 34,644-6) and the eluting solvents were delivered by the pump at a flow-rate of 0.5-1.5 mL $\min ^{-1}$. Melting points were uncorrected. ${ }^{1} \mathrm{H}$ and ${ }^{13} \mathrm{C}$ NMR spectra were recorded either on a Varian Unity or on a Bruker 300 instrument. Chemical shifts are reported in ppm $(\delta)$ relative to $\mathrm{CHCl}_{3}(\delta=$ 7.26) in $\mathrm{CDCl}_{3}$. Elemental analyses were performed on a Perkin Elmer 240B microanalyzer.

\section{N-Benzyl-C-(2-furyl)nitrone 2a}

To a well stirred solution of furfural $(0.96 \mathrm{~g}, 10 \mathrm{mmol})$ in dichloromethane $(20 \mathrm{ml})$ were added $\mathrm{N}$ benzylhydroxylamine $(1.23 \mathrm{~g}, 10 \mathrm{mmol})$ and magnesium sulfate $(2.4 \mathrm{~g}, 20 \mathrm{mmol})$. The resulting mixture was stirred for $4 \mathrm{~h}$ at which time the reaction mixture was filtered and the filtrate evaporated under reduced pressure. The residue was purified by column chromatography $\left(\mathrm{Et}_{2} \mathrm{O}\right)$ to give the nitrone $(1.78 \mathrm{~g}, 88 \%)$ as a crystalline solid: $\mathrm{mp} 99-101^{\circ} \mathrm{C} ; \mathrm{R}_{\mathrm{f}}\left(\mathrm{Et}_{2} \mathrm{O}\right)=0.36 ;{ }^{1} \mathrm{H} \mathrm{NMR}\left(\mathrm{CDCl}_{3}\right): \delta 4.99(\mathrm{~s}, 2 \mathrm{H}$, $\left.\mathrm{NCH}_{2} \mathrm{Ph}\right), 6.51\left(\mathrm{dd}, 1 \mathrm{H}, \mathrm{J}=1.7,3.4 \mathrm{~Hz}, \mathrm{H}_{4}\right), 7.36-7.44\left(\mathrm{~m}, 6 \mathrm{H}, \mathrm{ArH}\right.$ and $\left.\mathrm{H}_{3}\right), 7.50\left(\mathrm{~s}, 1 \mathrm{H}, \mathrm{H}_{1}\right), 7.75(\mathrm{~d}$, $\left.1 \mathrm{H}, \mathrm{J}=3.4 \mathrm{~Hz}, \mathrm{H}_{5}\right) ;{ }^{13} \mathrm{C} \mathrm{NMR}\left(\mathrm{CDCl}_{3}\right): \delta 69.6,112.3,115.4,125.2,129.0,129.1,129.4,132.8,143.7$, 146.8 .

Anal. Calcd for $\mathrm{C}_{12} \mathrm{H}_{11} \mathrm{NO}_{2}$ (201.22): C, 71.63; H, 5.51; N, 6.96. Found: C, 71.86; H, 5.38; N, 6.83.

\section{N-(4-Metoxybenzyl)-C-(2-furyl)nitrone $\mathbf{2 b}$}

The method described above to prepare 2a was carried out using N-(4methoxybenzyl)hydroxylamine $(1.53 \mathrm{~g}, 10 \mathrm{mmol})$ to give, after column chromatography $\left(\mathrm{Et}_{2} \mathrm{O}\right)$, pure 2b $(1.64 \mathrm{~g}, 71 \%)$ as a white solid;mp $108-110{ }^{\circ} \mathrm{C} ; \mathrm{R}_{\mathrm{f}}\left(\mathrm{Et}_{2} \mathrm{O}\right)=0.35 ;{ }^{1} \mathrm{H}$ NMR $\left(\mathrm{CDCl}_{3}\right)$ : $\delta 3.80(\mathrm{~s}, 3 \mathrm{H}$, $\left.\mathrm{OCH}_{3}\right), 4.93\left(\mathrm{~s}, 2 \mathrm{H}, \mathrm{NCH}_{2} \mathrm{Ph}\right), 6.50\left(\mathrm{dd}, 1 \mathrm{H}, \mathrm{J}=1.8,3.5 \mathrm{~Hz}, \mathrm{H}_{4}\right), 6.91(\mathrm{~m}, 2 \mathrm{H}, \mathrm{ArH}), 6.90(\mathrm{~m}, 2 \mathrm{H}$, $\operatorname{ArH}), 7.34\left(\mathrm{~d}, 1 \mathrm{H}, \mathrm{J}=1.8 \mathrm{~Hz}, \mathrm{H}_{3}\right), 7.43\left(\mathrm{~s}, 1 \mathrm{H}, \mathrm{H}_{1}\right), 7.74\left(\mathrm{~d}, 1 \mathrm{H}, \mathrm{J}=3.5 \mathrm{~Hz}, \mathrm{H}_{5}\right) ;{ }^{13} \mathrm{C} \mathrm{NMR}\left(\mathrm{CDCl}_{3}\right): \delta$ 55.3, 69.0, 112.3, 114.4, 115.3, 124.6, 124.8, 131.1, 143.6, 146.8, 160.2.

Anal Calcd. for $\mathrm{C}_{13} \mathrm{H}_{13} \mathrm{NO}_{3}(231.25)$ : C, 67.52; H, 5.67; N, 6.06. Found: C, 67.36; H, 5.52; N, 6.17. 
General Procedure 1,3-Dipolar Cycloaddition of Nitrones 2 with vinyl acetate 3a

To a solution of the corresponding nitrone $(1 \mathrm{mmol})$ in toluene was added vinyl acetate $(4.3 \mathrm{~g}, 50$ mmol) and the resulting solution was heated under an inert atmosphere (Ar) at reflux for 10 days at which time the mixture was cooled to ambient temperature and concentrated under reduced pressure. The diastereomeric ratio (d.r. \%) of the residue was determined by ${ }^{1} \mathrm{H}$ NMR analysis. The crude material was purified using a Chromatotron ${ }^{\circledR}(2 \mathrm{~mm}$ layer thickness).

\section{$\left(3 S^{*}, 5 R^{*}\right)-5$-(Acetoxy)-2-benzyl-3-(2-furyl)isoxazolidine $\mathbf{4 a}$}

$\mathrm{R}_{\mathrm{f}}$ (hexane-Et $\left.\mathrm{O}, 1: 1\right)=0.51 ;{ }^{1} \mathrm{H} \mathrm{NMR}\left(\mathrm{CDCl}_{3}, 55^{\circ} \mathrm{C}\right): \delta 2.08\left(\mathrm{~s}, 3 \mathrm{H}, \mathrm{CH}_{3}\right), 2.69(\mathrm{ddd}, 1 \mathrm{H}, \mathrm{J}=2.9$, 9.4, $\left.13.6 \mathrm{~Hz}, \mathrm{H}_{4 \mathrm{a}}\right), 2.91$ (ddd, $\left.1 \mathrm{H}, \mathrm{J}=6.8,7.9,13.6 \mathrm{~Hz}, \mathrm{H}_{4 \mathrm{~b}}\right), 3.91$ and $4.22(2 \mathrm{~d}, 2 \mathrm{H}, \mathrm{J}=14.5 \mathrm{~Hz}$, $\left.\mathrm{NCH}_{2} \mathrm{Ph}\right), 3.94\left(\mathrm{dd}, 1 \mathrm{H}, \mathrm{J}=7.9,9.4 \mathrm{~Hz}, \mathrm{H}_{3}\right), 6.31-6.36\left(\mathrm{~m}, 2 \mathrm{H}, \mathrm{H}_{3}\right.$, and $\left.\mathrm{H}_{4}\right), 6.37(\mathrm{dd}, 1 \mathrm{H}, \mathrm{J}=2.9,6.8$ $\left.\mathrm{Hz}, \mathrm{H}_{5}\right), 7.22-7.36(\mathrm{~m}, 5 \mathrm{H}, \mathrm{ArH}), 7.40\left(\mathrm{bs}, 1 \mathrm{H}, \mathrm{H}_{5}\right.$ ).

${ }^{13} \mathrm{C} \mathrm{NMR}\left(\mathrm{CDCl}_{3}, 55^{\circ} \mathrm{C}\right): \delta 21.2,41.8,60.1,62.4,95.2,108.8,110.5,127.3,128.1,129.3,136.3$, 142.8, 150.2, 170.4.

Anal Calcd. for $\mathrm{C}_{16} \mathrm{H}_{17} \mathrm{NO}_{4}(287.31)$ : C, 66.89; H, 5.96; N, 4.88. Found: C, 66.71; H, 5.86; N, 4.84.

$\left(3 S^{*}, 5 S^{*}\right)-5-($ Acetoxy)-2-benzyl-3-(2-furyl)isoxazolidine 5a

$\mathrm{R}_{\mathrm{f}}$ (hexane-Et $\left.\mathrm{O}, 1: 1\right)=0.44 ;{ }^{1} \mathrm{H} \mathrm{NMR}\left(\mathrm{CDCl}_{3}, 55^{\circ} \mathrm{C}\right): \delta 2.10\left(\mathrm{~s}, 3 \mathrm{H}, \mathrm{CH}_{3}\right), 2.63(\mathrm{dd}, 1 \mathrm{H}, \mathrm{J}=6.6$, $\left.13.2 \mathrm{~Hz}, \mathrm{H}_{4 \mathrm{a}}\right), 2.88\left(\mathrm{ddd}, 1 \mathrm{H}, \mathrm{J}=5.4,8.5,13.2 \mathrm{~Hz}, \mathrm{H}_{4 \mathrm{~b}}\right), 4.07$ and $4.15\left(2 \mathrm{~d}, 2 \mathrm{H}, \mathrm{J}=13.9 \mathrm{~Hz}, \mathrm{NCH}_{2} \mathrm{Ph}\right)$, $4.39\left(\mathrm{dd}, 1 \mathrm{H}, \mathrm{J}=6.8,8.5 \mathrm{~Hz}, \mathrm{H}_{3}\right), 6.23\left(\mathrm{~d}, 1 \mathrm{H}, \mathrm{J}=3.2 \mathrm{~Hz}, \mathrm{H}_{3}\right), 6.31-6.34\left(\mathrm{~m}, 1 \mathrm{H}, \mathrm{H}_{4}\right), 6.44(\mathrm{~d}, 1 \mathrm{H}, \mathrm{J}=$ $\left.5.4 \mathrm{~Hz}, \mathrm{H}_{5}\right), 7.25-7.40\left(\mathrm{~m}, 6 \mathrm{H}, \mathrm{ArH}\right.$ and $\left.\mathrm{H}_{5}\right) ;{ }^{13} \mathrm{C} \mathrm{NMR}\left(\mathrm{CDCl}_{3}, 55^{\circ} \mathrm{C}\right): \delta 21.2,41.4,60.3,62.1,96.9$, 108.0, 110.4, 127.4, 128.2, 129.3, 136.4, 142.6, 151.5, 169.8 .

Anal Calcd. for $\mathrm{C}_{16} \mathrm{H}_{17} \mathrm{NO}_{4}(287.31)$ : C, 66.89; H, 5.96; N, 4.88. Found C, 67.00; H, 5.73; N, 4.92.

$\left(3 S^{*}, 5 R^{*}\right)-5-($ Acetoxy)-2-(4-methoxybenzyl)benzyl-3-(2-furyl)isoxazolidine $\mathbf{4 b}$

$\mathrm{R}_{\mathrm{f}}$ (hexane-Et $\left.\mathrm{O}, 2: 1\right)=0.49 ;{ }^{1} \mathrm{H} \mathrm{NMR}\left(\mathrm{CDCl}_{3}, 55^{\circ} \mathrm{C}\right): \delta 2.09\left(\mathrm{~s}, 3 \mathrm{H}, \mathrm{CH}_{3}\right), 2.72(\mathrm{ddd}, 1 \mathrm{H}, \mathrm{J}=2.5$, 8.6, $\left.13.5 \mathrm{~Hz}, \mathrm{H}_{4 \mathrm{a}}\right), 2.88\left(\mathrm{ddd}, 1 \mathrm{H}, \mathrm{J}=6.4,8.0,13.5 \mathrm{~Hz}, \mathrm{H}_{4 \mathrm{~b}}\right), 3.76\left(\mathrm{~s}, 3 \mathrm{H}, \mathrm{OCH}_{3}\right), 3.90$ and $4.25(2 \mathrm{~d}, 2 \mathrm{H}$, $\left.\mathrm{J}=14.1 \mathrm{~Hz}, \mathrm{NCH}_{2} \mathrm{Ph}\right), 3.90\left(\mathrm{dd}, 1 \mathrm{H}, \mathrm{J}=8.0,8.6 \mathrm{~Hz}, \mathrm{H}_{3}\right), 6.30-6.34\left(\mathrm{~m}, 2 \mathrm{H}, \mathrm{H}_{3}\right.$, and $\left.\mathrm{H}_{4}\right), 6.41(\mathrm{dd}, 1 \mathrm{H}$, $\left.\mathrm{J}=2.5,6.4 \mathrm{~Hz}, \mathrm{H}_{5}\right), 6.78(\mathrm{~m}, 2 \mathrm{H}, \mathrm{ArH}), 7.22(\mathrm{~m}, 2 \mathrm{H}, \mathrm{ArH}), 7.39\left(\mathrm{bs}, 1 \mathrm{H}, \mathrm{H}_{5}\right) ;{ }^{13} \mathrm{C} \mathrm{NMR}\left(\mathrm{CDCl}_{3}, 55^{\circ} \mathrm{C}\right)$ $\delta 21.5,43.6,55.4,62.3,63.5,98.1,109.2,110.4,113.7,129.4,129.9,142.9,152.4,158.9,170.2$.

Anal Calcd. for : $\mathrm{C}_{17} \mathrm{H}_{19} \mathrm{NO}_{5}(317.13)$ : C, 64.34; H, 6.03; N, 4.41. Found C, 64.48; H, 5.96; N, 4.31. $\left(3 S^{*}, 5 S^{*}\right)-5-($ Acetoxy)-2-(4-methoxybenzyl)-3-(2-furyl)isoxazolidine $\mathbf{5 b}$

$\mathrm{R}_{\mathrm{f}}$ (hexane-Et $\left.\mathrm{O}_{2}, 2: 1\right)=0.38 ;{ }^{1} \mathrm{H} \mathrm{NMR}\left(\mathrm{CDCl}_{3}, 55^{\circ} \mathrm{C}\right): \delta 2.08\left(\mathrm{~s}, 3 \mathrm{H}, \mathrm{CH}_{3}\right), 2.55(\mathrm{ddd}, 1 \mathrm{H}, \mathrm{J}=1.1$, 
$\left.5.9,13.3 \mathrm{~Hz}, \mathrm{H}_{4 \mathrm{a}}\right), 2.90\left(\mathrm{ddd}, 1 \mathrm{H}, \mathrm{J}=6.0,9.1,13.3 \mathrm{~Hz}, \mathrm{H}_{4 \mathrm{~b}}\right), 3.76\left(\mathrm{~s}, 3 \mathrm{H}, \mathrm{OCH}_{3}\right), 4.12$ and $4.20(2 \mathrm{~d}, 2 \mathrm{H}$, $\left.\mathrm{J}=14.2 \mathrm{~Hz}, \mathrm{NCH}_{2} \mathrm{Ph}\right), 4.36\left(\mathrm{dd}, 1 \mathrm{H}, \mathrm{J}=5.9,9.1 \mathrm{~Hz}, \mathrm{H}_{3}\right), 6.21\left(\mathrm{~d}, 1 \mathrm{H}, \mathrm{J}=3.2 \mathrm{~Hz}, \mathrm{H}_{3}\right), 6.30-6.33(\mathrm{~m}$, $\left.1 \mathrm{H}, \mathrm{H}_{4}\right), 6.50\left(\mathrm{~d}, 1 \mathrm{H}, \mathrm{J}=1.1,6.0 \mathrm{~Hz}, \mathrm{H}_{5}\right), 6.78(\mathrm{~m}, 2 \mathrm{H}, \mathrm{ArH}), 7.22(\mathrm{~m}, 2 \mathrm{H}, \mathrm{ArH}), 7.40\left(\mathrm{bs}, 1 \mathrm{H}, \mathrm{H}_{5^{\prime}}\right)$; ${ }^{13} \mathrm{C} \mathrm{NMR}\left(\mathrm{CDCl}_{3}, 55^{\circ} \mathrm{C}\right): \delta 21.3,40.9,56.7,61.0,61.9,95.6,108.9,109.3,113.6,129.2,129.8,142.7$, $150.9,160.2,170.4$.

Anal. Calcd. for: $\mathrm{C}_{17} \mathrm{H}_{19} \mathrm{NO}_{5}$ (317.13): C, 64.34; H, 6.03; N, 4.41. Found C, 64.56; H, 6.17; N, 4.55.

General Procedure 1,3-Dipolar Cycloaddition of Nitrones 2 with ethyl vinyl ether $\mathbf{3 b}$

To a solution of the corresponding nitrone $(1 \mathrm{mmol})$ in toluene was added ethyl vinyl ether $(3.6 \mathrm{~g}$, $50.0 \mathrm{mmol}$ ) and the resulting solution was heated under an inert atmosphere (Ar) at reflux for 10 days at which time the mixture was cooled to ambient temperature and concentrated under reduced pressure. The diastereomeric ratio (d.r. \%) was determined on the residue by ${ }^{1} \mathrm{H}$ NMR analysis. The crude material was purified with the Chromatotron ${ }^{\circledR}(2 \mathrm{~mm}$ layer thickness).

(3S*,5R*)-5-Ethoxy-3-(2-furyl)-2-benzylisoxazolidine 4c

$\mathrm{R}_{\mathrm{f}}$ (hexane-Et $\left.\mathrm{O}_{2}, 3: 1\right)=0.55 ;{ }^{1} \mathrm{H} \mathrm{NMR}\left(\mathrm{CDCl}_{3}, 55^{\circ} \mathrm{C}\right): \delta 1.22\left(\mathrm{t}, 3 \mathrm{H}, \mathrm{J}=7.1 \mathrm{~Hz}, \mathrm{CH}_{3} \mathrm{CH}_{2} \mathrm{O}\right), 2.58$ (ddd, $1 \mathrm{H}, \mathrm{J}=1.7,6.9,12.7 \mathrm{~Hz} \mathrm{H}_{4 \mathrm{a}}$ ), 2.70 (ddd, $1 \mathrm{H}, \mathrm{J}=5.1,8.2,12.7 \mathrm{~Hz}, \mathrm{H}_{4 \mathrm{~b}}$ ), 3.47 (q, 2H, J = 7.1 Hz, $\mathrm{CH}_{3} \mathrm{CH}_{2} \mathrm{O}$ ), $4.13\left(\mathrm{~s}, 2 \mathrm{H}, \mathrm{NCH}_{2} \mathrm{Ph}\right), 4.39$ (t, $\left.1 \mathrm{H}, \mathrm{J}=7.6 \mathrm{~Hz}, \mathrm{H}_{3}\right), 5.25\left(\mathrm{dd}, 1 \mathrm{H}, \mathrm{J}=1.7,5.1 \mathrm{~Hz}, \mathrm{H}_{5}\right), 6.31$ $\left(\mathrm{dd}, 1 \mathrm{H}, \mathrm{J}=1.8,3.3 \mathrm{~Hz}, \mathrm{H}_{4}\right), 6.35\left(\mathrm{~d}, 1 \mathrm{H}, \mathrm{J}=3.3 \mathrm{~Hz}, \mathrm{H}_{3}\right), 7.18-7.60\left(\mathrm{~m}, 6 \mathrm{H}, \mathrm{ArH}\right.$ and $\left.\mathrm{H}_{5^{\prime}}\right) .{ }^{13} \mathrm{C}$ NMR $\left(\mathrm{CDCl}_{3}, 55^{\circ} \mathrm{C}\right): \delta 14.9,41.5,59.9,63.1,63.5,102.9,107.0,110.2,126.8,128.0,128.8,137.8,142.0$, 150.2 .

Anal. Calcd. for $\mathrm{C}_{16} \mathrm{H}_{19} \mathrm{NO}_{3}(273.33)$ : C, 70.31; H, 7.01; N, 5.12. Found C, 70.26; H, 7.22; N, 5.18.

$\left(3 S^{*}, 5 S^{*}\right)-5$-Ethoxy-3-(2-furyl)-2-benzylisoxazolidine $\mathbf{5 c}$

$\mathrm{R}_{\mathrm{f}}$ (hexane-Et $\left.\mathrm{O}_{2} \mathrm{O}, 3: 1\right)=0.48 ;{ }^{1} \mathrm{H} \mathrm{NMR}\left(\mathrm{CDCl}_{3}, 55^{\circ} \mathrm{C}\right): \delta 1.15\left(\mathrm{t}, 3 \mathrm{H}, \mathrm{J}=7.1 \mathrm{~Hz}, \mathrm{CH}_{3} \mathrm{CH}_{2} \mathrm{O}\right), 2.57$ $\left(\mathrm{ddd}, 1 \mathrm{H}, \mathrm{J}=3.3,6.5,13.2 \mathrm{~Hz}, \mathrm{H}_{4 \mathrm{a}}\right.$ ) $2.76\left(\mathrm{ddd}, 1 \mathrm{H}, \mathrm{J}=6.5,8.1,13.2 \mathrm{~Hz}, \mathrm{H}_{4 \mathrm{~b}}\right.$ ), 3.71 (q, 2H, J = 7.1 Hz, $\left.\mathrm{CH}_{3} \mathrm{CH}_{2} \mathrm{O}\right), 3.80$ and $4.20\left(2 \mathrm{~d}, 2 \mathrm{H}, \mathrm{J}=14.4 \mathrm{~Hz}, \mathrm{NCH}_{2} \mathrm{Ph}\right), 4.30\left(\mathrm{t}, 1 \mathrm{H}, \mathrm{J}=7.3 \mathrm{~Hz}, \mathrm{H}_{3}\right), 5.17$ (dd, 1H, J $\left.=3.3,6.5 \mathrm{~Hz}, \mathrm{H}_{5}\right), 6.16\left(\mathrm{~d}, 1 \mathrm{H}, \mathrm{J}=3.3 \mathrm{~Hz}, \mathrm{H}_{3}\right), 6.27\left(\mathrm{dd}, 1 \mathrm{H}, \mathrm{J}=1.8,3.3 \mathrm{~Hz}, \mathrm{H}_{4}\right), 7.18-7.60(\mathrm{~m}, 6 \mathrm{H}$, ArH and $\left.\mathrm{H}_{5}\right) ;{ }^{13} \mathrm{C} \mathrm{NMR}\left(\mathrm{CDCl}_{3}, 55^{\circ} \mathrm{C}\right): \delta 15.0,42.0,61.4,63.0,63.3,100.9,108.3,110.1,126.9$, 127.8, 128.7, 137.4, 142.4, 151.0.

Anal. Calcd. for $\mathrm{C}_{16} \mathrm{H}_{19} \mathrm{NO}_{3}(273.33)$ : C, 66.89; H, 5.96; N, 4.88. Found C, 66.72; H, 5.93; N, 4.95.

$\left(3 S^{*}, 5 R^{*}\right)-5-E t h o x y-3-(2-f u r y l)-2-(4-m e t o x y b e n z y l)$ isoxazolidine $\mathbf{4 d}$

$\mathrm{R}_{\mathrm{f}}$ (hexane-Et $\left.\mathrm{O}, 7: 3\right)=0.33 ;{ }^{1} \mathrm{H} \mathrm{NMR}\left(\mathrm{CDCl}_{3}, 55^{\circ} \mathrm{C}\right): \delta 0.90\left(\mathrm{t}, 3 \mathrm{H}, \mathrm{J}=6.1 \mathrm{~Hz}, \mathrm{CH}_{3} \mathrm{CH}_{2} \mathrm{O}\right), 2.56$ $\left(\mathrm{ddd}, 1 \mathrm{H}, \mathrm{J}=1.5,7.6,13.4 \mathrm{~Hz}, \mathrm{H}_{4 \mathrm{a}}\right), 2.69\left(\mathrm{ddd}, 1 \mathrm{H}, \mathrm{J}=5.3,7.6,13.4 \mathrm{~Hz}, \mathrm{H}_{4 \mathrm{~b}}\right), 3.75$ and $4.13(2 \mathrm{~d}, 2 \mathrm{H}, \mathrm{J}$ 
$\left.=14.5 \mathrm{~Hz}, \mathrm{NCH}_{2} \mathrm{Ph}\right), 3.86\left(\mathrm{~s}, 3 \mathrm{H}, \mathrm{OCH}_{3}\right), 4.20\left(\mathrm{q}, 2 \mathrm{H}, \mathrm{J}=6.1 \mathrm{~Hz}, \mathrm{CH}_{3} \mathrm{CH}_{2} \mathrm{O}\right), 4.38(\mathrm{t}, 1 \mathrm{H}, \mathrm{J}=7.6 \mathrm{~Hz}$, $\left.\mathrm{H}_{3}\right), 5.24\left(\mathrm{dd}, 1 \mathrm{H}, \mathrm{J}=1.5,5.3 \mathrm{~Hz}, \mathrm{H}_{5}\right), 6.30\left(\mathrm{dd}, 1 \mathrm{H}, \mathrm{J}=1.9,3.1 \mathrm{~Hz}, \mathrm{H}_{4}\right), 6.33\left(\mathrm{~d}, 1 \mathrm{H}, \mathrm{J}=3.1 \mathrm{~Hz}, \mathrm{H}_{3}\right)$, $6.98(\mathrm{~m}, 2 \mathrm{H}, \mathrm{ArH}), 7.35$ (m, 2H, $\mathrm{ArH}), 7.33\left(\mathrm{bs}, 1 \mathrm{H}, \mathrm{H}_{5}\right) ;{ }^{13} \mathrm{C} \mathrm{NMR}\left(\mathrm{CDCl}_{3}, 55^{\circ} \mathrm{C}\right): \delta 15.0,41.4,55.2$, 63.1, 63.7, 66.7, 103.4, 108.7, 110.2, 113.5, 128.7, 130.8, 142.2, 150.4, 158.6.

Anal. Calcd. for $\mathrm{C}_{17} \mathrm{H}_{21} \mathrm{NO}_{4}(303.35)$ : C, 67.31; H, 6.98; N, 4.62. Found C, 67.34; H, 6.80; N, 4.45.

\section{$\left(3 S^{*}, 5 S^{*}\right)-5-E t h o x y-3-(2-f u r y l)-2-(4-m e t o x y b e n z y l)$ isoxazolidine $\mathbf{5 d}$}

$\mathrm{R}_{\mathrm{f}}$ (hexane-Et $\left.\mathrm{O}, 7: 3\right)=0.29 ;{ }^{1} \mathrm{H}$ NMR $\left(\mathrm{CDCl}_{3}, 55^{\circ} \mathrm{C}\right): \delta 1.20\left(\mathrm{t}, 3 \mathrm{H}, \mathrm{J}=5.7 \mathrm{~Hz}, \mathrm{CH}_{3} \mathrm{CH}_{2} \mathrm{O}\right), 2.55$ (ddd, $\left.1 \mathrm{H}, \mathrm{J}=3.1,8.0,13.4 \mathrm{~Hz}, \mathrm{H}_{4 \mathrm{a}}\right), 2.74\left(\mathrm{ddd}, 1 \mathrm{H}, \mathrm{J}=6.5,8.0,13.4 \mathrm{~Hz}, \mathrm{H}_{4 \mathrm{~b}}\right), 3.76\left(\mathrm{~s}, 3 \mathrm{H}, \mathrm{OCH}_{3}\right), 4.08$ $\left(\mathrm{s}, 2 \mathrm{H}, \mathrm{NCH}_{2} \mathrm{Ph}\right), 4.24\left(\mathrm{q}, 2 \mathrm{H}, \mathrm{J}=5.7 \mathrm{~Hz}, \mathrm{CH}_{3} \mathrm{CH}_{2} \mathrm{O}\right), 4.30\left(\mathrm{t}, 1 \mathrm{H}, \mathrm{J}=8.0 \mathrm{~Hz}, \mathrm{H}_{3}\right), 5.17(\mathrm{dd}, 1 \mathrm{H}, \mathrm{J}=$ 3.1, $\left.6.5 \mathrm{~Hz}, \mathrm{H}_{5}\right), 6.15\left(\mathrm{~d}, 1 \mathrm{H}, \mathrm{J}=3.1 \mathrm{~Hz}, \mathrm{H}_{3}\right), 6.26\left(\mathrm{dd}, 1 \mathrm{H}, \mathrm{J}=1.5,3.1 \mathrm{~Hz}, \mathrm{H}_{4}\right), 6.88(\mathrm{~m}, 2 \mathrm{H}, \operatorname{ArH})$, $7.27(\mathrm{~m}, 2 \mathrm{H}, \mathrm{ArH}), 7.33\left(\mathrm{~d}, 1 \mathrm{H}, \mathrm{J}=1.5 \mathrm{~Hz}, \mathrm{H}_{5}\right) ;{ }^{13} \mathrm{C} \mathrm{NMR}\left(\mathrm{CDCl}_{3}, 55^{\circ} \mathrm{C}\right): \delta 15.0,41.8,55.5,62.4$, 64.0, 66.9, 102.8, 107.2, 110.3, 113.4, 126.7, 132.2, 142.6, 148.5, 158.8.

Anal. Calcd. for $\mathrm{C}_{17} \mathrm{H}_{21} \mathrm{NO}_{4}(303.35)$ : C, 67.31; H, 6.98; N, 4.62. Found C, 67.16; H, 7.02; N, 4.77.

General Procedure 1,3-Dipolar Cycloaddition of Nitrones 2 with methyl fumarate 6 and methyl maleate 7

To a solution of the corresponding nitrone $(1 \mathrm{mmol})$ in toluene was added the corresponding alkene $(0.72 \mathrm{~g}, 5.0 \mathrm{mmol})$ and the resulting solution was heated under an inert atmosphere (Ar) at reflux for $12 \mathrm{~h}$ at which time the mixture was cooled to ambient temperature and concentrated under reduced pressure. The diastereomeric ratio (d.r. \%) was determined on the residue by ${ }^{1} \mathrm{H}$ NMR analysis. The crude material was purified with the Chromatotron ${ }^{\circledR}(2 \mathrm{~mm}$ layer thickness).

$\left(3 S^{*}, 4 S^{*}, 5 S^{*}\right)-2-B e n z y l-3-(2-f u r y l)-4,5-b i s($ methoxycarbonyl)isoxazolidine $\mathbf{8 a}$

$\mathrm{R}_{\mathrm{f}}\left(\right.$ hexane-Et $\left.\mathrm{O}_{2} \mathrm{O}, 3: 2\right)=0.62 ;{ }^{1} \mathrm{H} \mathrm{NMR}\left(\mathrm{CDCl}_{3}, 55^{\circ} \mathrm{C}\right): \delta 3.70\left(\mathrm{~s}, 3 \mathrm{H}, \mathrm{OCH}_{3}\right), 3.75\left(\mathrm{~s}, 3 \mathrm{H}, \mathrm{OCH}_{3}\right)$, 3.88 and $4.11\left(2 \mathrm{~d}, 2 \mathrm{H}, \mathrm{J}=14.7 \mathrm{~Hz}, \mathrm{NCH}_{2} \mathrm{Ph}\right), 4.06\left(\mathrm{dd}, 1 \mathrm{H}, \mathrm{J}=7.1,8.6 \mathrm{~Hz}, \mathrm{H}_{4}\right), 4.56(\mathrm{~d}, 1 \mathrm{H}, \mathrm{J}=8.6$ $\left.\mathrm{Hz}, \mathrm{H}_{3}\right), 5.13\left(\mathrm{~d}, 1 \mathrm{H}, \mathrm{J}=7.1 \mathrm{~Hz}, \mathrm{H}_{5}\right), 6.27\left(\mathrm{~d}, 1 \mathrm{H}, \mathrm{J}=3.3 \mathrm{~Hz}, \mathrm{H}_{3}\right), 6.29\left(\mathrm{dd}, 1 \mathrm{H}, \mathrm{J}=1.7,3.3 \mathrm{~Hz}, \mathrm{H}_{4}\right)$, 7.18-7.38 (m, 6H, ArH and $\left.\mathrm{H}_{5}\right) ;{ }^{13} \mathrm{C} \mathrm{NMR}\left(\mathrm{CDCl}_{3}, 55^{\circ} \mathrm{C}\right): \delta 52.0,52.3,55.7,59.1,64.5,66.5,109.3$, 110.4, 127.3, 128.1, 128.7, 136.6, 142.4, 149.4, 169.1, 171.1.

Anal. Calcd. for $\mathrm{C}_{18} \mathrm{H}_{19} \mathrm{NO}_{6}(345.35)$ : C, 62.60; H, 5.55; N, 4.06. Found C, 62.43; H, 5.67; N, 4.12.

\section{$\left(3 S^{*}, 4 R^{*}, 5 R^{*}\right)-2-B e n z y l-3-(2-f u r y l)-4,5-b i s(m e t h o x y c a r b o n y l)$ isoxazolidine $9 \mathbf{a}$}

$\mathrm{R}_{\mathrm{f}}($ hexane-Et $2 \mathrm{O}, 3: 2)=0.52 ;{ }^{1} \mathrm{H} \mathrm{NMR}\left(\mathrm{CDCl}_{3}, 55^{\circ} \mathrm{C}\right): \delta 3.70\left(\mathrm{~s}, 3 \mathrm{H}, \mathrm{OCH}_{3}\right), 3.77\left(\mathrm{~s}, 3 \mathrm{H}, \mathrm{OCH}_{3}\right)$, 4.03 and $4.09\left(2 \mathrm{~d}, 2 \mathrm{H}, \mathrm{J}=14.4 \mathrm{~Hz}, \mathrm{NCH}_{2} \mathrm{Ph}\right), 4.16\left(\mathrm{dd}, 1 \mathrm{H}, \mathrm{J}=4.0,7.8 \mathrm{~Hz}, \mathrm{H}_{4}\right), 4.20(\mathrm{~d}, 1 \mathrm{H} \mathrm{J}=7.8$ $\left.\mathrm{Hz}, \mathrm{H}_{3}\right), 4.89\left(\mathrm{~d}, 1 \mathrm{H}, \mathrm{J}=4.0 \mathrm{~Hz}, \mathrm{H}_{5}\right), 6.29\left(\mathrm{dd}, 1 \mathrm{H}, \mathrm{J}=1.7,3.3 \mathrm{~Hz}, \mathrm{H}_{4^{\prime}}\right), 6.35\left(\mathrm{~d}, 1 \mathrm{H}, \mathrm{J}=3.3 \mathrm{~Hz}, \mathrm{H}_{3^{\prime}}\right)$, 
7.18-7.38 (m, 6H, ArH and $\left.\mathrm{H}_{5}\right) ;{ }^{13} \mathrm{C} \mathrm{NMR}\left(\mathrm{CDCl}_{3}, 55^{\circ} \mathrm{C}\right): \delta 52.0,52.4,54.8,59.1,64.5,66.5,109.3$, $110.4,127.0,128.0,128.4,136.4,143.0,149.4,170.8,170.9$.

Anal. Calcd. for $\mathrm{C}_{18} \mathrm{H}_{19} \mathrm{NO}_{6}(345.35)$ : C, 62.60; H, 5.55; N, 4.06. Found C, 62.47; H, 5.71; N, 4.13.

$\left(3 S^{*}, 4 S^{*}, 5 S^{*}\right)-2-(4 . M e t h o x y b e n z y l)-3-(2-f u r y l)-4,5-b i s($ methoxycarbonyl)isoxazolidine $\mathbf{8 b}$

$\mathrm{R}_{\mathrm{f}}($ hexane-Et $\mathrm{O}, 7: 3)=0.11 ;{ }^{1} \mathrm{H} \mathrm{NMR}\left(\mathrm{CDCl}_{3}, 55^{\circ} \mathrm{C}\right): \delta 3.70\left(\mathrm{~s}, 3 \mathrm{H}, \mathrm{OCH}_{3}\right), 3.75\left(\mathrm{~s}, 3 \mathrm{H}, \mathrm{OCH}_{3}\right)$, $3.76\left(\mathrm{~s}, 3 \mathrm{H}, \mathrm{OCH}_{3}\right), 3.82$ and $4.04\left(2 \mathrm{~d}, 2 \mathrm{H}, \mathrm{J}=14.5 \mathrm{~Hz}, \mathrm{NCH}_{2} \mathrm{Ph}\right), 4.12\left(\mathrm{dd}, 1 \mathrm{H}, \mathrm{J}=4.4,7.6 \mathrm{~Hz}, \mathrm{H}_{4}\right)$, $4.19\left(\mathrm{~d}, 1 \mathrm{H}, \mathrm{J}=7.6 \mathrm{~Hz}, \mathrm{H}_{3}\right), 4.89\left(\mathrm{~d}, 1 \mathrm{H}, \mathrm{J}=4.4 \mathrm{~Hz}, \mathrm{H}_{5}\right), 6.30\left(\mathrm{dd}, 1 \mathrm{H}, \mathrm{J}=1.8,3.2 \mathrm{~Hz}, \mathrm{H}_{4}\right), 6.33$ (d, $\left.1 \mathrm{H}, \mathrm{J}=3.2 \mathrm{~Hz}, \mathrm{H}_{3}\right), 6.79(\mathrm{~m}, 2 \mathrm{H}, \mathrm{ArH}), 7.23(\mathrm{~m}, 2 \mathrm{H}, \mathrm{ArH}), 7.35\left(\mathrm{dd}, 1 \mathrm{H}, \mathrm{J}=0.8,1.8 \mathrm{~Hz}, \mathrm{H}_{5}\right) ;{ }^{13} \mathrm{C}$ NMR $\left(\mathrm{CDCl}_{3}, 55^{\circ} \mathrm{C}\right): \delta 52.3,52.5,55.1,55.7,58.5,66.1,77.5,109.3,110.5,113.6,128.5,129.7$, 142.9, 149.5, 159.0, 170.9, 171.1.

Anal. Calcd. for $\mathrm{C}_{19} \mathrm{H}_{21} \mathrm{NO}_{7}(375.37)$ : C, 60.79; H, 5.64; N, 3.73. Found C, 60.63; H, 4.94; N, 3.79.

$\left(3 S^{*}, 4 R^{*}, 5 R^{*}\right)-2-(4-M e t h o x y b e n z y l)-3-(2-f u r y l)-4,5-$ bis(methoxycarbonyl)isoxazolidine $\mathbf{9 b}$

$\mathrm{R}_{\mathrm{f}}$ (hexane-Et $\left.\mathrm{O}, 7: 3\right)=0.16 ;{ }^{1} \mathrm{H} \mathrm{NMR}\left(\mathrm{CDCl}_{3}, 55^{\circ} \mathrm{C}\right): \delta 3.70\left(\mathrm{~s}, 3 \mathrm{H}, \mathrm{OCH}_{3}\right), 3.75\left(\mathrm{~s}, 3 \mathrm{H}, \mathrm{OCH}_{3}\right)$, $3.76\left(\mathrm{~s}, 3 \mathrm{H}, \mathrm{OCH}_{3}\right), 3.83$ and $4.02\left(2 \mathrm{~d}, 2 \mathrm{H}, \mathrm{J}=14.4 \mathrm{~Hz}, \mathrm{NCH}_{2} \mathrm{Ph}\right), 4.03\left(\mathrm{t}, 1 \mathrm{H}, \mathrm{J}=7.3 \mathrm{~Hz}, \mathrm{H}_{4}\right), 4.52(\mathrm{~d}$, $\left.1 \mathrm{H}, \mathrm{J}=7.5 \mathrm{~Hz}, \mathrm{H}_{3}\right), 5.10\left(\mathrm{~d}, 1 \mathrm{H}, \mathrm{J}=7.1 \mathrm{~Hz}, \mathrm{H}_{5}\right), 6.25\left(\mathrm{~d}, 1 \mathrm{H}, \mathrm{J}=3.1 \mathrm{~Hz}, \mathrm{H}_{4}\right), 6.31-6.35\left({\left.\mathrm{~m} 1 \mathrm{H}, \mathrm{H}_{3}\right)}\right)$, $6.79(\mathrm{~m}, 2 \mathrm{H}, \mathrm{ArH}), 7.19(\mathrm{~m}, 2 \mathrm{H}, \mathrm{ArH}), 7.31\left(\mathrm{bs}, 1 \mathrm{H}, \mathrm{H}_{5}\right) ;{ }^{13} \mathrm{C} \mathrm{NMR}\left(\mathrm{CDCl}_{3}, 55^{\circ} \mathrm{C}\right): \delta 52.0,52.3,54.8$, 55.1, 58.5, 66.1, 77.5, 109.2, 110.4, 113.7, 128.4, 130.0, 142.4, 149.5, 159.1, 169.1, 170.9.

Anal. Calcd. for $\mathrm{C}_{19} \mathrm{H}_{21} \mathrm{NO}_{7}(375.37)$ : C, 60.79; H, 5.64; N, 3.73. Found C, 60.94; H, 5.48; N, 3.78.

$\left(3 S^{*}, 4 R^{*}, 5 S^{*}\right)-2-B e n z y l-3-(2-f u r y l)-4,5-b i s($ methoxycarbonyl)isoxazolidine $\mathbf{8 c}$

$\mathrm{R}_{\mathrm{f}}$ (hexane-Et $\left.\mathrm{O}_{2}, 3: 2\right)=0.43 ; \mathrm{mp} 75^{\circ} \mathrm{C} ;{ }^{1} \mathrm{H} \mathrm{NMR}\left(\mathrm{CDCl}_{3}, 55^{\circ} \mathrm{C}\right): \delta 3.64\left(\mathrm{~s}, 3 \mathrm{H}, \mathrm{OCH}_{3}\right), 3.72(\mathrm{~s}$, $\left.3 \mathrm{H}, \mathrm{OCH}_{3}\right), 4.02\left(\mathrm{dd}, 1 \mathrm{H}, \mathrm{J}=8.8,9.0 \mathrm{~Hz}, \mathrm{H}_{4}\right), 4.05\left(\mathrm{~s}, 2 \mathrm{H}, \mathrm{NCH}_{2} \mathrm{Ph}\right), 4.40\left(\mathrm{~d}, 1 \mathrm{H}, \mathrm{J}=8.8 \mathrm{~Hz}, \mathrm{H}_{3}\right), 4.88$ $\left(\mathrm{d}, 1 \mathrm{H}, \mathrm{J}=9.0 \mathrm{~Hz}, \mathrm{H}_{5}\right), 6.31\left(\mathrm{dd}, 1 \mathrm{H}, \mathrm{J}=1.7,3.3 \mathrm{~Hz}, \mathrm{H}_{4^{\prime}}\right), 6.33\left(\mathrm{~d}, 1 \mathrm{H}, \mathrm{J}=3.3 \mathrm{~Hz}, \mathrm{H}_{3^{\prime}}\right), 7.18-7.32(\mathrm{~m}$, $5 \mathrm{H}, \mathrm{ArH}), 7.39\left(\mathrm{~d}, 1 \mathrm{H}, \mathrm{J}=1.7 \mathrm{~Hz}, \mathrm{H}_{5}\right) ;{ }^{13} \mathrm{C} \mathrm{NMR}\left(\mathrm{CDCl}_{3}, 55^{\circ} \mathrm{C}\right): \delta 51.8,52.0,52.1,55.5,60.3,66.0$, $109.3,110.4,127.1,128.0,128.1,136.9,143.0,149.2,168.9,169.5$.

Anal. Calcd. for $\mathrm{C}_{18} \mathrm{H}_{19} \mathrm{NO}_{6}$ (345.35): C, 62.60; H, 5.55; N, 4.06. Found 62.72; H, 5.43; N, 3.98 .

$(3 S * 4 S *, 5 R *)-2-B e n z y l-3-(2-f u r y l)-4,5$-bis(methoxycarbonyl)isoxazolidine $9 \mathbf{c}$

$\mathrm{R}_{\mathrm{f}}$ (hexane-Et $\left.\mathrm{O}_{2}, 3: 2\right)=0.38 ; \mathrm{mp} 91-93 \cdot \mathrm{C} ;{ }^{1} \mathrm{H} \mathrm{NMR}\left(\mathrm{CDCl}_{3}, 55^{\circ} \mathrm{C}\right): \delta 3.40\left(\mathrm{~s}, 3 \mathrm{H}, \mathrm{OCH}_{3}\right), 3.75(\mathrm{~s}$, $\left.3 \mathrm{H}, \mathrm{OCH}_{3}\right), 3.86$ and $4.16\left(2 \mathrm{~d}, 2 \mathrm{H}, \mathrm{J}=14.5 \mathrm{~Hz}, \mathrm{NCH}_{2} \mathrm{Ph}\right), 4.04\left(\mathrm{dd}, 1 \mathrm{H}, \mathrm{J}=8.1,8.8 \mathrm{~Hz}, \mathrm{H}_{4}\right), 4.38(\mathrm{~d}$, $\left.1 \mathrm{H}, \mathrm{J}=8.1 \mathrm{~Hz}, \mathrm{H}_{3}\right), 4.76\left(\mathrm{~d}, 1 \mathrm{H}, \mathrm{J}=8.8 \mathrm{~Hz}, \mathrm{H}_{5}\right), 6.30\left(\mathrm{dd}, 1 \mathrm{H}, \mathrm{J}=1.7,3.1 \mathrm{~Hz}, \mathrm{H}_{4}\right), 6.39(\mathrm{~d}, 1 \mathrm{H}, \mathrm{J}=3.1$ $\left.\mathrm{Hz}, \mathrm{H}_{3}\right), 7.16-7.40\left(\mathrm{~m}, 6 \mathrm{H}, \mathrm{ArH}\right.$ and $\left.\mathrm{H}_{5}\right) ;{ }^{13} \mathrm{C} \mathrm{NMR}\left(\mathrm{CDCl}_{3}, 55^{\circ} \mathrm{C}\right): \delta 51.8,52.0,52.2,55.2,58.8,65.0$, $109.5,110.6,127.3,128.1,129.0,135.8,142.3,148.4,168.6,169.6$. 
Anal. Calcd. for $\mathrm{C}_{18} \mathrm{H}_{19} \mathrm{NO}_{6}$ (345.35): C, 62.60; H, 5.55; N, 4.06. Found C, 62.47; H, 5.67; N, 4.10.

$\left(3 S^{*}, 4 R^{*}, 5 S^{*}\right)-2-(4 . M e t h o x y b e n z y l)-3-(2-f u r y l)-4,5-b i s($ methoxycarbonyl)isoxazolidine 8d

$\mathrm{R}_{\mathrm{f}}$ (hexane-Et $\left.\mathrm{O}_{2} 3: 2\right)=0.18 ; \mathrm{mp} 74-76^{\circ} \mathrm{C} ;{ }^{1} \mathrm{H} \mathrm{NMR}\left(\mathrm{CDCl}_{3}, 55^{\circ} \mathrm{C}\right): \delta 3.63\left(\mathrm{~s}, 3 \mathrm{H}, \mathrm{OCH}_{3}\right), 3.70(\mathrm{~s}$, $\left.3 \mathrm{H}, \mathrm{OCH}_{3}\right), 3.72\left(\mathrm{~s}, 3 \mathrm{H}, \mathrm{OCH}_{3}\right), 3,97$ and $4.03\left(2 \mathrm{~d}, 2 \mathrm{H}, \mathrm{J}=13.9 \mathrm{~Hz}, \mathrm{NCH}_{2} \mathrm{Ph}\right), 3.99(\mathrm{t}, 1 \mathrm{H}, \mathrm{J}=8.9 \mathrm{~Hz}$, $\left.\mathrm{H}_{4}\right), 4.40\left(\mathrm{~d}, 1 \mathrm{H}, \mathrm{J}=8.9 \mathrm{~Hz}, \mathrm{H}_{3}\right), 4.85\left(\mathrm{~d}, 1 \mathrm{H}, \mathrm{J}=8.9 \mathrm{~Hz}, \mathrm{H}_{5}\right), 6.29-6.36\left(\mathrm{~m}, 2 \mathrm{H}, \mathrm{H}_{4}\right.$ and $\left.\mathrm{H}_{3}\right), 6.78(\mathrm{~m}$, $2 \mathrm{H}, \mathrm{ArH}), 7.21(\mathrm{~m}, 2 \mathrm{H}, \mathrm{ArH}), 7.37$ (bs, $\left.1 \mathrm{H}, \mathrm{H}_{5}\right) ;{ }^{13} \mathrm{C} \mathrm{NMR}\left(\mathrm{CDCl}_{3}, 55^{\circ} \mathrm{C}\right): \delta 51.9,52.0,55.0,55.3$, 59.5, 65.7, 76.8, 109.2, 110.3, 113.5, 128.8, 130.0, 142.9, 149.1, 158.9, 168.8, 169.5.

Anal. Calcd. for $\mathrm{C}_{19} \mathrm{H}_{21} \mathrm{NO}_{7}(375.37)$ : C, 60.79; H, 5.64; N, 3.73. Found C, 60.67; H, 5.75; N, 3.65.

$\left(3 S^{*}, 4 S^{*}, 5 R^{*}\right)-2-(4-M e t h o x y b e n z y l)-3-(2-f u r y l)-4,5-b i s(m e t h o x y c a r b o n y l)$ isoxazolidine 9d

$\mathrm{R}_{\mathrm{f}}$ (hexane-Et $\left.\mathrm{O}_{2} 3: 2\right)=0.14 ; \mathrm{mp} 91-93^{\circ} \mathrm{C} ;{ }^{1} \mathrm{H} \mathrm{NMR}\left(\mathrm{CDCl}_{3}, 55^{\circ} \mathrm{C}\right): \delta 3.42\left(\mathrm{~s}, 3 \mathrm{H}, \mathrm{OCH}_{3}\right), 3.75(\mathrm{~s}$, $\left.3 \mathrm{H}, \mathrm{OCH}_{3}\right), 3.78\left(\mathrm{~s}, 3 \mathrm{H}, \mathrm{OCH}_{3}\right), 4.05\left(\mathrm{t}, 1 \mathrm{H}, \mathrm{J}=8.0 \mathrm{~Hz}, \mathrm{H}_{4}\right), 4.25$ and $4.75(2 \mathrm{~d}, 2 \mathrm{H}, \mathrm{J}=13.5 \mathrm{~Hz}$, $\left.\mathrm{NCH}_{2} \mathrm{Ph}\right), 4.38\left(\mathrm{~d}, 1 \mathrm{H}, \mathrm{J}=8.0 \mathrm{~Hz}, \mathrm{H}_{3}\right), 4.55\left(\mathrm{~d}, 1 \mathrm{H}, \mathrm{J}=8.0 \mathrm{~Hz}, \mathrm{H}_{5}\right), 6.34\left(\mathrm{~m}, 1 \mathrm{H}, \mathrm{H}_{4}\right), 6.41(\mathrm{~m}, 1 \mathrm{H}$, $\mathrm{H}_{3}$ ), $6.84(\mathrm{~m}, 2 \mathrm{H}, \mathrm{ArH}), 7.24(\mathrm{~m}, 2 \mathrm{H}, \mathrm{ArH}), 7.38$ (bs, $\left.1 \mathrm{H}, \mathrm{H}_{5}\right) ;{ }^{13} \mathrm{C} \mathrm{NMR}\left(\mathrm{CDCl}_{3}, 55^{\circ} \mathrm{C}\right): \delta 51.8,52.0$, 55.2, 55.3, 58.5, 64.6, 75.8, 109.4, 110.7, 113.7, 127.7, 130.5, 142.5, 148.5, 159.2, 168.7, 169.6.

Anal. Calcd. for $\mathrm{C}_{19} \mathrm{H}_{21} \mathrm{NO}_{7}(375.37)$ : C, 60.79; H, 5.64; N, 3.73. Found C, 60.91; H, 5.51; N, 3.79.

General Procedure for the reduction of isoxazolidines $\mathbf{8}$ and $\mathbf{9}$. Synthesis of pyrrolidin-2-ones $\mathbf{1 0}$ and 11

To a solution of the corresponding isoxazolidine $(1 \mathrm{mmol})$ in THF $(10 \mathrm{~mL})$ were added acetic acid $(20 \mathrm{~mL})$ and water $(10 \mathrm{~mL})$. The resulting solution was then treated with $\mathrm{Zn}$ dust $(0.4 \mathrm{~g}, 6.1 \mathrm{mmol})$ and heated at $60{ }^{\circ} \mathrm{C}$ for $5 \mathrm{~h}$. The reaction mixture was cooled to room temperature and then filtered through a short pad of Celite. The filtrate was neutralized with saturated aqueous sodium carbonate until $\mathrm{pH}=$ 8-9 and then extracted with $\mathrm{CH}_{2} \mathrm{Cl}_{2}(3 \times 20 \mathrm{~mL})$. The combined organic extracts were joined, washed with brine, dried over $\mathrm{MgSO}_{4}$ and evaporated under reduced pressure. The obtained crude material was purified with the Chromatotron ${ }^{\circledR}$ (2 mm layer thickness).

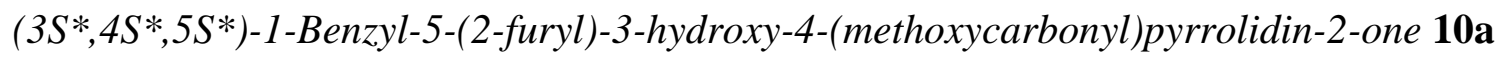

$\mathrm{R}_{\mathrm{f}}\left(\mathrm{Et}_{2} \mathrm{O}\right)=0.49 ; \mathrm{mp} 129-131^{\circ} \mathrm{C} ;{ }^{1} \mathrm{H} \mathrm{NMR}\left(\mathrm{CDCl}_{3}\right): \delta 3.57\left(\mathrm{dd}, 1 \mathrm{H}, \mathrm{J}=3.8,8.1 \mathrm{~Hz}, \mathrm{H}_{4}\right), 3.59$ and $4.96\left(2 \mathrm{~d}, 2 \mathrm{H}, \mathrm{J}=15.0 \mathrm{~Hz}, \mathrm{NCH}_{2} \mathrm{Ph}\right), 3.65\left(\mathrm{~s}, 3 \mathrm{H}, \mathrm{OCH}_{3}\right), 4.50(\mathrm{bs}, 1 \mathrm{H}, \mathrm{OH}), 4.79$ (d, 1H, J = 3.8 Hz, $\left.\mathrm{H}_{5}\right), 4.90\left(\mathrm{~d}, 1 \mathrm{H}, \mathrm{J}=8.1 \mathrm{~Hz}, \mathrm{H}_{3}\right), 6.22\left(\mathrm{~d}, 1 \mathrm{H}, \mathrm{J}=3.2 \mathrm{~Hz}, \mathrm{H}_{3^{\prime}}\right), 6.30\left(\mathrm{dd}, 1 \mathrm{H}, \mathrm{J}=1.8,3.2 \mathrm{~Hz}, \mathrm{H}_{4^{\prime}}\right), 7.18$ $7.39\left(\mathrm{~m}, 6 \mathrm{H}, \mathrm{ArH}\right.$ and $\left.\mathrm{H}_{5}\right) ;{ }^{13} \mathrm{C} \mathrm{NMR}\left(\mathrm{CDCl}_{3}\right): \delta 44.8,48.6,52.6,54.4,69.9,110.2,110.5,127.7$, $128.4,128.6,134.9,143.5,149.5,169.7,172.6$.

Anal. Calcd. for $\mathrm{C}_{17} \mathrm{H}_{17} \mathrm{NO}_{5}(315.32)$ : C, 64.75; H, 5.43; N, 4.44. Found C, 64.53; H, 5.60; N, 4.54. 
$\left(3 R^{*}, 4 R^{*}, 5 S^{*}\right)-1-B e n z y l-5-(2-f u r y l)-3-h y d r o x y-4-(m e t h o x y c a r b o n y l) p y r r o l i d i n-2-o n e ~ 11 a$

$\mathrm{R}_{\mathrm{f}}\left(\mathrm{Et}_{2} \mathrm{O}\right)=0.33 ;{ }^{1} \mathrm{H} \mathrm{NMR}\left(\mathrm{CDCl}_{3}\right): \delta 3.52\left(\mathrm{t}, 1 \mathrm{H}, \mathrm{J}=7.0 \mathrm{~Hz}, \mathrm{H}_{4}\right), 3.54\left(\mathrm{~s}, 3 \mathrm{H}, \mathrm{OCH}_{3}\right), 3.60(\mathrm{bs}, 1 \mathrm{H}$, $\mathrm{OH}), 3.71$ and $3.78\left(2 \mathrm{~d}, 2 \mathrm{H}, \mathrm{J}=14.9 \mathrm{~Hz}, \mathrm{NCH}_{2} \mathrm{Ph}\right), 4.51\left(\mathrm{~d}, 1 \mathrm{H}, \mathrm{J}=7.0 \mathrm{~Hz}, \mathrm{H}_{5}\right), 4.67(\mathrm{~d}, 1 \mathrm{H}, \mathrm{J}=7.0$ $\left.\mathrm{Hz}, \mathrm{H}_{3}\right), 6.30\left(\mathrm{~d}, 1 \mathrm{H}, \mathrm{J}=2.2 \mathrm{~Hz}, \mathrm{H}_{3}\right), 6.36\left(\mathrm{dd}, 1 \mathrm{H}, \mathrm{J}=1.8,2.8 \mathrm{~Hz}, \mathrm{H}_{4}\right), 7.01-7.38(\mathrm{~m}, 6 \mathrm{H}$, ArH and $\left.\mathrm{H}_{5}\right) ;{ }^{13} \mathrm{C} \mathrm{NMR}\left(\mathrm{CDCl}_{3}\right): \delta 45.0,48.1,52.2,53.8,70.4,110.5,110.8,127.9,128.4(2 \mathrm{C}), 135.4,143.6$, 148.0, 169.4, 172.2.

Anal. Calcd. for $\mathrm{C}_{17} \mathrm{H}_{17} \mathrm{NO}_{5}(315.32)$ : C, 64.75; H, 5.43; N, 4.44. Found C, 64.89; H, 5.68; N, 4.27.

$\left(3 S^{*}, 4 S^{*}, 5 S^{*}\right)-1-(4-M e t h o x y b e n z y l)-5-(2-f u r y l)-3-h y d r o x y-4-(m e t h o x y c a r b o n y l) p y r r o l i d i n-2-o n e$ 10b

$\mathrm{R}_{\mathrm{f}}\left(\mathrm{Et}_{2} \mathrm{O}\right)=0.47 ; \mathrm{mp} 111-113^{\circ} \mathrm{C} ;{ }^{1} \mathrm{H} \mathrm{NMR}\left(\mathrm{CDCl}_{3}\right): \delta 3.54$ and $4.90(2 \mathrm{~d}, 2 \mathrm{H}, \mathrm{J}=14.7 \mathrm{~Hz}$, $\left.\mathrm{NCH}_{2} \mathrm{Ph}\right), 3.55\left(\mathrm{dd}, 1 \mathrm{H}, \mathrm{J}=4.0,7.8 \mathrm{~Hz}, \mathrm{H}_{4}\right), 3.64\left(\mathrm{~s}, 3 \mathrm{H}, \mathrm{OCH}_{3}\right), 3.75\left(\mathrm{~s}, 3 \mathrm{H}, \mathrm{OCH}_{3}\right), 4.80(\mathrm{~d}, 1 \mathrm{H}, \mathrm{J}=$ $\left.4.0 \mathrm{~Hz}, \mathrm{H}_{5}\right), 4.92\left(\mathrm{~d}, 1 \mathrm{H}, \mathrm{J}=7.8 \mathrm{~Hz}, \mathrm{H}_{3}\right), 5.28(\mathrm{bs}, 1 \mathrm{H}, \mathrm{OH}), 6.22\left(\mathrm{~d}, 1 \mathrm{H}, \mathrm{J}=3.1 \mathrm{~Hz}, \mathrm{H}_{3}\right), 6.29(\mathrm{dd}, 1 \mathrm{H}$, $\left.\mathrm{J}=1.9,3.1 \mathrm{~Hz}, \mathrm{H}_{4^{\prime}}\right), 6.81(\mathrm{~m}, 2 \mathrm{H}, \mathrm{ArH}), 7.09(\mathrm{~m}, 2 \mathrm{H}, \mathrm{ArH}), 7.34\left(\mathrm{~d}, 1 \mathrm{H}, \mathrm{J}=1.9 \mathrm{~Hz}, \mathrm{H}_{5^{\prime}}\right) ;{ }^{13} \mathrm{C}$ NMR $\left(\mathrm{CDCl}_{3}\right): \delta 44.1,48.6,52.1,54.2,55.1,69.8,110.0,110.3,113.8,126.8,129.6,143.4,149.5,159.0$, 169.6, 172.7.

Anal. Calcd. for $\mathrm{C}_{18} \mathrm{H}_{19} \mathrm{NO}_{6}$ (345.35): C, 64.75; H, 5.43; N, 4.44. Found C, 64.87; H, 5.57; N, 4.29.

$\left(3 R^{*}, 4 R^{*}, 5 S^{*}\right)-1-(4-M e t h o x y b e n z y l)-5-(2-f u r y l)-3-h y d r o x y-4-(m e t h o x y c a r b o n y l) p y r r o l i d i n-2-o n e ~ 11 \mathbf{b}$

$\mathrm{R}_{\mathrm{f}}\left(\mathrm{Et}_{2} \mathrm{O}\right)=0.30 ;{ }^{1} \mathrm{H} \mathrm{NMR}\left(\mathrm{CDCl}_{3}\right): \delta 3.49\left(\mathrm{t}, 1 \mathrm{H}, \mathrm{J}=7.1 \mathrm{~Hz}, \mathrm{H}_{4}\right), 3.54\left(\mathrm{~s}, 3 \mathrm{H}, \mathrm{OCH}_{3}\right), 3.62$ and $4.98\left(2 \mathrm{~d}, 2 \mathrm{H}, \mathrm{J}=14.6 \mathrm{~Hz}, \mathrm{NCH}_{2} \mathrm{Ph}\right), 3.76\left(\mathrm{~s}, 3 \mathrm{H}, \mathrm{OCH}_{3}\right), 3.78\left(\mathrm{~d}, 1 \mathrm{H}, \mathrm{J}=7.1 \mathrm{~Hz}, \mathrm{H}_{5}\right), 4.47(\mathrm{bs}, 1 \mathrm{H}$, $\mathrm{OH}), 4.66\left(\mathrm{~d}, 1 \mathrm{H}, \mathrm{J}=7.1 \mathrm{~Hz}, \mathrm{H}_{3}\right), 6.31\left(\mathrm{dd}, 1 \mathrm{H}, \mathrm{J}=0.6,3.3 \mathrm{~Hz}, \mathrm{H}_{3}\right), 6.36\left(\mathrm{dd}, 1 \mathrm{H}, \mathrm{J}=1.8,3.3 \mathrm{~Hz}, \mathrm{H}_{4^{\prime}}\right)$, $6.77(\mathrm{~m}, 2 \mathrm{H}, \mathrm{ArH}), 6.93(\mathrm{~m}, 2 \mathrm{H}, \mathrm{ArH}), 7.37\left(\mathrm{dd}, 1 \mathrm{H}, \mathrm{J}=0.6,1.8 \mathrm{~Hz}, \mathrm{H}_{5}\right) ;{ }^{13} \mathrm{C} \mathrm{NMR}\left(\mathrm{CDCl}_{3}\right): \delta 44.3$, 48.0, 52.2, 53.7, 55.2, 70.5, 110.8, 110.8, 114.0, 127.5, 129.8, 143.2, 148.2, 159.2, 169.5, 172.0.

Anal. Calcd. for $\mathrm{C}_{18} \mathrm{H}_{19} \mathrm{NO}_{6}(345.35)$ : C, 64.75; H, 5.43; N, 4.44. Found C, 64.61; H, 5.33; N, 4.59.

$\left(3 R^{*}, 4 S^{*}, 5 S^{*}\right)-1-B e n z y l-5-(2-f u r y l)-3-h y d r o x y-4-(m e t h o x y c a r b o n y l) p y r r o l i d i n-2-o n e$ 10c

$\mathrm{R}_{\mathrm{f}}\left(\mathrm{Et}_{2} \mathrm{O}\right)=0.45 ; \mathrm{mp} 133-135^{\circ} \mathrm{C} ;{ }^{1} \mathrm{H} \mathrm{NMR}\left(\mathrm{CDCl}_{3}\right): \delta 3.45\left(\mathrm{t}, 1 \mathrm{H}, \mathrm{J}=8.5 \mathrm{~Hz}, \mathrm{H}_{4}\right), 3.57$ and 4.90 $\left(2 \mathrm{~d}, 2 \mathrm{H}, \mathrm{J}=14.8 \mathrm{~Hz}, \mathrm{NCH}_{2} \mathrm{Ph}\right), 3.65\left(\mathrm{~s}, 3 \mathrm{H}, \mathrm{OCH}_{3}\right), 4.64\left(\mathrm{~d}, 1 \mathrm{H}, \mathrm{J}=8.5 \mathrm{~Hz}, \mathrm{H}_{5}\right), 4.69$ (d, $1 \mathrm{H}, \mathrm{J}=8.5$ $\mathrm{Hz}, \mathrm{H}_{3}$ ), 5.30 (bs, 1H, OH), 6.30 (dd, 1H, J = 0.9, 3.2 Hz, $\mathrm{H}_{3^{\prime}}$ ), 6.33 (dd, 1H, J = 1.8, 3.2 Hz, H H $^{\prime}$ ), 7.05$7.12(\mathrm{~m}, 2 \mathrm{H}, \mathrm{ArH}), 7.20-7.30(\mathrm{~m}, 3 \mathrm{H}, \mathrm{ArH}), 7.40\left(\mathrm{bs}, 1 \mathrm{H}, \mathrm{H}_{5}\right) ;{ }^{13} \mathrm{C} \mathrm{NMR}\left(\mathrm{CDCl}_{3}\right): \delta 44.8,51.5,52.5$, 53.7, 72.0, 110.4, 111.2, 127.6, 128.2, 128.5, 135.2, 143.8, 148.5, 171.3, 172.6.

Anal. Calcd. for $\mathrm{C}_{17} \mathrm{H}_{17} \mathrm{NO}_{5}(315.32)$ : C, 64.75; H, 5.43; N, 4.44. Found C, 64.83; H, 5.57; N, 4.33.

$\left(3 S^{*}, 4 R^{*}, 5 S^{*}\right)-1-B e n z y l-5-(2-f u r y l)-3-h y d r o x y-4-($ methoxycarbonyl)pyrrolidin-2-one 11c

$\mathrm{R}_{\mathrm{f}}\left(\mathrm{Et}_{2} \mathrm{O}\right)=0.45 ; \mathrm{mp} 121-123^{\circ} \mathrm{C} ;{ }^{1} \mathrm{H} \mathrm{NMR}\left(\mathrm{CDCl}_{3}\right): \delta 3.33\left(\mathrm{t}, 1 \mathrm{H}, \mathrm{J}=9.4 \mathrm{~Hz}, \mathrm{H}_{4}\right), 3.49(\mathrm{~s}, 3 \mathrm{H}$, $\left.\mathrm{OCH}_{3}\right), 3.56$ and 5,03 (2d, 2H, J = 14.7 Hz, $\left.\mathrm{NCH}_{2} \mathrm{Ph}\right), 4.40$ (bs, 1H, OH), 4.65 (d, 1H, J = 8.9 Hz, H 5 ), 
$5.12\left(\mathrm{~d}, 1 \mathrm{H}, \mathrm{J}=9,8 \mathrm{~Hz}, \mathrm{H}_{3}\right), 6.21\left(\mathrm{~d}, 1 \mathrm{H}, \mathrm{J}=3.2 \mathrm{~Hz}, \mathrm{H}_{3}\right), 6.29\left(\mathrm{dd}, 1 \mathrm{H}, \mathrm{J}=1.8,3.2 \mathrm{~Hz}, \mathrm{H}_{4}\right), 7.16-7.50$ $\left(\mathrm{m}, 6 \mathrm{H}, \mathrm{ArH}\right.$ and $\left.\mathrm{H}_{5}\right) ;{ }^{13} \mathrm{C} \mathrm{NMR}\left(\mathrm{CDCl}_{3}\right): \delta 45.0,50.9,52.2,52.6,69.7,110.4,110.4,128.0,128.4$, 128.9, 134.9, 143.5, 148.3, 169.0, 172.8 .

Anal. Calcd. for $\mathrm{C}_{17} \mathrm{H}_{17} \mathrm{NO}_{5}$ (315.32): C, 64.75; H, 5.43; N, 4.44. Found C, 64.88; H, 5.23; N, 4.31.

$\left(3 R^{*}, 4 S^{*}, 5 S^{*}\right)-1-(4-M e t h o x y b e n z y l)-5-(2-f u r y l)-3-h y d r o x y-4-(m e t h o x y c a r b o n y l)$ pyrrolidin-2-one 10d

$\mathrm{R}_{\mathrm{f}}\left(\mathrm{Et}_{2} \mathrm{O}\right)=0.43 ; \mathrm{mp} 138-140^{\circ} \mathrm{C} ;{ }^{1} \mathrm{H} \mathrm{NMR}\left(\mathrm{CDCl}_{3}\right): \delta 3.41\left(\mathrm{t}, 1 \mathrm{H}, \mathrm{J}=8.5 \mathrm{~Hz}, \mathrm{H}_{4}\right), 3.48$ and 4.84 $\left(2 \mathrm{~d}, 2 \mathrm{H}, \mathrm{J}=14.6 \mathrm{~Hz}, \mathrm{NCH}_{2} \mathrm{Ph}\right), 3.64\left(\mathrm{~s}, 3 \mathrm{H}, \mathrm{OCH}_{3}\right), 3.73\left(\mathrm{~s}, 3 \mathrm{H}, \mathrm{OCH}_{3}\right), 4.60\left(\mathrm{~d}, 1 \mathrm{H}, \mathrm{J}=8.5 \mathrm{~Hz}, \mathrm{H}_{5}\right)$, $4.65\left(\mathrm{dd}, 1 \mathrm{H}, \mathrm{J}=2.8,8.5 \mathrm{~Hz}, \mathrm{H}_{3}\right), 5.30(\mathrm{~d}, 1 \mathrm{H}, \mathrm{J}=2.8 \mathrm{~Hz}, \mathrm{OH}), 6.30\left(\mathrm{dd}, 1 \mathrm{H}, \mathrm{J}=0.9,3.2 \mathrm{~Hz}, \mathrm{H}_{3}\right), 6.32$ $\left(\mathrm{dd}, 1 \mathrm{H}, \mathrm{J}=1.8,3.2 \mathrm{~Hz}, \mathrm{H}_{4}\right), 6.60(\mathrm{~m}, 2 \mathrm{H}, \mathrm{ArH}), 6.94(\mathrm{~m}, 2 \mathrm{H}, \mathrm{ArH}), 7.38\left(\mathrm{bs}, 1 \mathrm{H}, \mathrm{H}_{5}\right) ;{ }^{13} \mathrm{C}$ NMR $\left(\mathrm{CDCl}_{3}\right): \delta 44.2,51.5,52.5,53.5,55.1,72.1,110.4,111.1,113.9,127.3,129.6,143.7,148.7,159.0$, 171.3, 172.5.

Anal. Calcd. for $\mathrm{C}_{18} \mathrm{H}_{19} \mathrm{NO}_{6}$ (345.35): C, 62.60; H, 5.55; N, 4.06. Found C, 62.75; H, 5.65; N, 4.17.

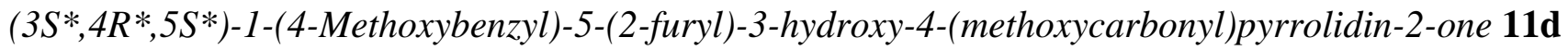

$\mathrm{R}_{\mathrm{f}}\left(\mathrm{Et}_{2} \mathrm{O}\right)=0.40 ;{ }^{1} \mathrm{H}$ NMR $\left(\mathrm{CDCl}_{3}\right): \delta 3.32\left(\mathrm{t}, 1 \mathrm{H}, \mathrm{J}=9.7 \mathrm{~Hz}, \mathrm{H}_{4}\right), 3.40$ and $4.97(2 \mathrm{~d}, 2 \mathrm{H}, \mathrm{J}=14.7$ $\mathrm{Hz}, \mathrm{NCH}_{2} \mathrm{Ph}$ ), 3.47 (s, 3H, $\left.\mathrm{OCH}_{3}\right), 3.77$ (s, 3H, $\left.\mathrm{OCH}_{3}\right), 4.60$ (bs, 1H, OH), 4.64 (d, 1H, J = 9.7 Hz, H $)_{5}$, $5.14\left(\mathrm{~d}, 1 \mathrm{H}, \mathrm{J}=9.7 \mathrm{~Hz}, \mathrm{H}_{3}\right), 6.20\left(\mathrm{~d}, 1 \mathrm{H}, \mathrm{J}=3.0 \mathrm{~Hz}, \mathrm{H}_{3^{\prime}}\right), 6.28\left(\mathrm{dd}, 1 \mathrm{H}, \mathrm{J}=1.8,3.0 \mathrm{~Hz}, \mathrm{H}_{4^{\prime}}\right), 6.82(\mathrm{~m}$, $2 \mathrm{H}, \mathrm{ArH}), 7.08(\mathrm{~m}, 2 \mathrm{H}, \mathrm{ArH}), 7.32\left(\mathrm{~d}, 1 \mathrm{H}, \mathrm{J}=1.8 \mathrm{~Hz}, \mathrm{H}_{5}\right) ;{ }^{13} \mathrm{C} \mathrm{NMR}\left(\mathrm{CDCl}_{3}\right): \delta 44.4,50.9,52.5,52.6$, $55.3,70.0,110.4,110.5,114.2,125.5,129.8,143.5,148.5,159.4,169.1,173.2$.

Anal. Calcd. for $\mathrm{C}_{18} \mathrm{H}_{19} \mathrm{NO}_{6}(345.35)$ : C, 62.60; H, 5.55; N, 4.06. Found C, 62.55; H, 5.69; N, 3.98 .

Acknowledgments: This work was supported by research funds provided by the Direccion General de Enseñanza Superior del Ministerio de Educacion and Cultura (Project PB97-1014. Madrid, Spain).

\section{References and Notes}

1. a) Torssell, K.G.B. Nitrile oxides, nitrones and nitronates in Organic Synthesis; VCH: New York, 1988; b) Tuffariello, J.J. 1,3-Dipolar Cycloaddition Chemistry; Padwa, A., Ed.; Wiley: New York, 1984; Vol. 12, p. 83; c) Gothelf, K.V.; Jorgensen, K.A. Chem. Rev. 1999, 99, 863; d) Frederickson, M. Tetrahedron 1997, 53, 403; e) Confalone, P.N.; Huie, E.M. Org. React. 1988, 36, 1; f) Padwa, A. In Comprehemsive Organic Synthesis; Trost, B.M.; Fleming, I., Eds.; Pergamon: Oxford, 1991, Vol. 4, p. 1069; g) Wade, P.A. In Comprehemsive Organic Synthesis; Trost, B.M.; Fleming, I., Eds.; Pergamon: Oxford, 1991, Vol. 4, p. 1111; h) Chiacchio, U.; Resciffina, A.; Romeo, G. In Targets in Heterocyclic Systems; Attanasi, O.; Spinelli, D., Eds.; Italian Chemical Society: Roma, 1997, Vol.1, p. 225; i) Merino, P.; Tejero, T. Molecules 1999, 4, 165 and references cited therein. 
2. For some particular examples see: a) Camiletti, C.; Poletti, L.; Trombini, C. J. Org. Chem. 1994, 59, 6843; b) Basha, A.; Henry, R.; McLaughlin, M.A.; Ratajczyk, J.D.; Wittenberger, S.J. J. Org. Chem. 1994, 59, 6103; c) Moriyama, S.; Vallee, Y. Synthesis 1998, 393.

3. Merchan, F.L.; Merino, P.; Rojo, I.; Tejero, T.; Dondoni, A. Tetrahedron: Asymmetry 1996, 7, 667.

4. a) Tejero, T.; Dondoni, A.; Rojo, I.; Merchan, F.L.; Merino, P. Tetrahedron 1997, 53, 3301; b) Merino, P.; Anoro, S.; Franco, S.; Merchan, F.L.; Tejero, T.; Tu on, V. J. Org. Chem. 2000, in press.

5. Merino, P.; Anoro, S.; Merchan, F.L.; Tejero, T. Heterocycles 2000, in press.

6. Dondoni, A.; Franco, S.; Junquera, F.; Merchan, F.L.; Merino, P.; Tejero, T. Synth. Commun. 1994, 24, 2537.

7. Aurich, H.-G.; Franzke, M.; Keiselheim, H.P. Tetrahedron 1992, 48, 663.

8. The authors have deposited atomic coordinates for the structure of $\mathbf{2 a}$ with the Cambridge Crystallographic Data Centre. The coordinates can be obtained on request, from the director, Cambridge Crystallographic Data Centre, 12 Union Road, Cambridge, CB2 1EZ, UK.

9. For a study on the cycloaddition of nitrones 2 with alkyl acrylates see ref. $4 \mathrm{~b}$.

10. a) Jorgensen, K.A.; Gothelf, K.V. Acta Chem. Scand. 1996, 50, 652; b) Cordero, F.M.; Aniquini, B.; Goti, A.; Brandi, A. Tetrahedron 1993, 49, 9867; c) Bimanand, A.Z.; Houk, K.N. Tetrahedron Lett. 1983, 24, 435; d) Dicken, C.M.; DeShong, P. J. Org. Chem. 1982, 47, 2047; e) DeShong, P.; Dicken, C.M.; Staib, R.R.; Freyer, A.J.; Weinreb, S.M. J. Org. Chem. 1982, 47, 4397; f) Cristina, D.; DeMicheli, C.; Gandolfi, R. J. Chem. Soc. Perkin Trans 1 1979, 2891.

11. Collins, I.; Nadin, A.; Holmes, A.B.; Long, M.A.; Man, J.; Baker, R. J. Chem. Soc. Perkin Trans 1 1994, 2205. In general, electron-rich alkenes are expected to give LUMO(nitrone)HOMO(alkene) controlled 1,3-dipolar cycloadditions. See: Seerden, J.-P. G.; Kuypers, M.M.M.; Scheeren, H.W. Tetrahedron 1995, 6, 1441 and references therein.

12. PM3 calculations were carried out using MOPAC 97 as implemented in the WINMOPAC 2.0 package (Fujitsu, 1998).

13. Inter alia: a) Rispens, M.T.; Keller, E.; Lange, B.; Zijlstra, R.W.J.; Feringa, B.L. Tetrahedron: Asymmetry 1994, 5, 607; b) Chiacchio, U.; Casuscelli, F.; Corsaro, A.; Rescifina, A.; Romeo, G.; Uccella, N. Tetrahedron 1994, 50, 6671; c) Chiacchio, U.; Buemi, G.; Casuscelli, F.; Procopio, A.; Rescifina, A.; Romeo, G. Tetrahedron 1994, 50, 5503.

14. Semiempirical geometry optimizations for all systems were carried out at the AM1 and PM3 levels of theory as implemented in WINMOPAC 2.0. Fujitsu Limited. 1998.

15. Ab initio calculations were performed using Gaussian 98, Revision A.3, M. Frisch, J.; Trucks, G. W.; Schlegel, H. B.; Scuseria, G. E.; Robb, M. A.; Cheeseman, J. R.; Zakrzewski, V. G.; Montgomery Jr., J. A.; Stratmann, R. E.; Burant, J. C.; Dapprich, S.; Millam, J. M.; Daniels, A. D.; Kudin, K. N.; Strain, M. C.; Farkas, O.; Tomasi, J.; Barone, V.; Cossi, M.; Cammi, R.; Mennucci, B.; Pomelli, C.; Adamo, C.; Clifford, S.; Ochterski, J.; Petersson, G. A.; Ayala, P. Y.; 
Cui, Q.; Morokuma, K.; Malick, D. K.; Rabuck, A. D.; Raghavachari, K.; Foresman, J. B.; Cioslowski, J.; Ortiz, J. V.; Stefanov, B. B.; Liu, G.; Liashenko, A.; Piskorz, P.; Komaromi, I.; Gomperts, R.; Martin, R. L.; Fox, D. J.; Keith, T.; Al-Laham, M. A.; Peng, C. Y.; Nanayakkara, A.; Gonzalez, C.; Challacombe, M.; Gill, P. M. W.; Johnson, B.; Chen, W.; Wong, M. W.; Andres, J. L.; Gonzalez, C.; Head-Gordon, M.; Replogle, E. S. and Pople, J. A. Gaussian, Inc., Pittsburgh PA, 1998.

16. The study was carried out with the N-methyl nitrone and vinyl acetate (or methyl vinyl ether). For a study of the same reaction with methyl acrylate see ref. $4 \mathrm{~b}$.

Samples Availability: Available from MDPI.

(C) 2000 by MDPI (http://www.mdpi.org). Reproduction is permitted for noncommercial purposes. 